\title{
Dijital İşletmeler ve Kullanıcı Deneyimi: Nitel Bir Araştırma (Digital Businesses and User Experience: A Qualitative Research)
}

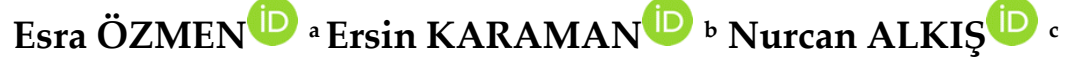 \\ a Ankara Hacı Bayram Veli Üniversitesi, Ankara, Türkiye. esra.ozmen@hbv.edu.tr \\ b Ankara Hacı Bayram Veli Üniversitesi, Ankara, Türkiye. ersin.karaman@hbv.edu.tr \\ c Başkent Üniversitesi, Ankara, Türkiye. nalkis@baskent.edu.tr
}

\begin{tabular}{|c|c|}
\hline MAKALE BİLGİsi் & ÖZET \\
\hline Anahtar Kelimeler: & Amaç - Bu çalışmada İnternet üzerinden alışveriş imkânı sunan e-ticaret sitelerinde müşterilerin \\
\hline $\begin{array}{l}\text { E-ticaret } \\
\text { Müsteri denevimi }\end{array}$ & $\begin{array}{l}\text { doğrudan etkileşimde oldukları e-ticaret web sayfası arayüz tasarımlarının gerçek bir alışveriş } \\
\text { ortamında müşteri deneyimleri ile değerlendirilmesi amaçlanmıştır. }\end{array}$ \\
\hline
\end{tabular}

Arayüz Değerlendirme

Nitel Araştırma Tasarımı

Gönderilme Tarihi 2 Temmuz 2021

Revizyon Tarihi 22 Eylül 2021 Kabul Tarihi 26 Eylül 2021

Makale Kategorisi: Araştırma Makalesi
Yöntem - Çalışma kapsamında ürün kategorileri, hedef kitleleri ve müşteri grupları gibi kriterler göZ önünde bulundurularak çeşitli e-ticaret siteleri incelenmiştir. Söz konusu e-ticaret web siteleri içerisinden etik kurallar çerçevesinde değerlendirme izni alınmış olan bir e-ticaret sitesinde müşteri deneyimleri gerçekleştirilmiştir. Araştırmada örneklem grubunun seçiminde maksimum çeşitlilik örnekleme yöntemi kullanılmıştır. Toplamda 32 gönüllü katılımcıya çeşitli görevler verilmiş ve gerçek bir alışveriş sürecini tamamlamaları istenmiştir. Alışveriş sürecini tamamlayan katılımcılar ile yapılandırılmamış mülakat gerçekleştirilmiştir. Görüşme formu ile toplanan nitel veriler MAXQDA 2020 yazılımı kullanılarak içerik analizi yapılmıştır.

Bulgular - Elde edilen bulgulara göre, katılımcılar ana sayfa hakkında kategori, menü, görsellik ve sadelik gibi noktalarda pozitif yorumlar yaparken renk, ürün konumlandırması, resimler, ürün bilgilendirmeleri gibi bölümlerde ise negatif görüşler sunmuşlardır. Katılımcı görüşlerinin \% $75,7(28)^{\prime}$ si e-ticaret sitesini kullanmaktan memnuniyet duyulduğunu ifade ederken memnuniyetsizlik belirten görüşler \%13,5 (5) dilimindedir. Katılımcı görüşlerinden \%62,3 (33)ü olumlu ifadeler barındırırken $\% 37,7$ (20)sinde olumsuz ifadeler yer almaktadır.

Tartışma - E-ticaret web sayfaları ile ilgili çeşitli çalışmalar olsa da, müşteri deneyimi sonucunda web sayfası arayüzünün nitel verilerle değerlendirmesinin alanyazına katkı sağlayacağı düşünülmektedir. $\mathrm{Bu}$ çalışma, gerçek bir alışveriş süreci sonrasında yapılan mülakat sonucunda e-ticaret sayfasının doğrudan müşteri gözü ile yorumlanması açısından önemli görülmektedir. Çalışma sonuçları doğrultusunda web sayfalarının kullanılabilirliği ve iyileştirilmesi noktasında çeşitli öneriler sunulmuştur. Bu öneriler 1şığında çalışmanın; işletmelerin rekabet üstünlüğü sağlaması, müşteri memnuniyetinin oluşturulması ve işletmelerin dijital ortamda varlıklarını sürdürmeleri konusunda katkı sunması beklenmektedir.

\begin{tabular}{|c|c|}
\hline ARTICLE INFO & ABSTRACT \\
\hline Keywords: & Purpose - In this study, it is aimed to evaluate the user interface designs of e-commerce sites offerin \\
\hline E-commerce & 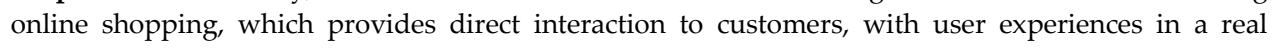 \\
\hline Customer experience & \\
\hline Interface evaluation & Design/methodology/approach - In the scope of this study, various e-commerce sites were examined \\
\hline Qualitative Research Design & by considering several criteria including product categories, target audiences and customer groups. \\
\hline Received 2 July 2021 & $\begin{array}{l}\text { Among examined e-commerce web sites, customer experiences were performed on an specified e- } \\
\text { commerce site for which ethical clearance was obtained for evaluation. In order to select the sample }\end{array}$ \\
\hline Revised 22 September 2021 & group, maximum variation sampling method was employed. In total 32 volunteer participants, were \\
\hline Accepted 26 September 2021 & $\begin{array}{l}\text { given various tasks and ensured to complete a real shopping process. Unstructured interviews were } \\
\text { conducted with the participants who completed the shopping process. Qualitative data collected with }\end{array}$ \\
\hline \multirow{2}{*}{$\begin{array}{l}\text { Article Classification: } \\
\text { Research Article }\end{array}$} & the interview form were analyzed using the MAXQDA 2020 software. \\
\hline & $\begin{array}{l}\text { Results - According to results, while the participants made positive comments about the home page on } \\
\text { points such as category, menu, visuality and simplicity, they presented negative opinions in sections } \\
\text { such as color, product design, pictures, product information. While } 75.7 \% \text { (28) of the participants' } \\
\text { opinions stated that they were satisfied with using the e-commerce site, the opinions expressing } \\
\text { dissatisfaction were in the } 13.5 \% \text { (5) section. While } 62.3 \% \text { (33) of the participants' opinions include } \\
\text { positive statements, } 37.7 \%(20) \text { have negative statements. }\end{array}$ \\
\hline
\end{tabular}

\footnotetext{
* Bu çalışma "E-ticaret Sitelerinde Çok Kanallı Kullanılabilirlik ve Kullanıcı Deneyimi Çalışması" adlı Doktora tezinden türetilmiştir.
}

* Sorumlu yazar: Ersin KARAMAN, ersin.karaman@hbv.edu.tr

\section{Önerilen Atıf/Suggested Citation}

Özmen, E., Karaman, E., Alkış, N..(2021). Dijital İşletmeler ve Kullanıcı Deneyimi: Nitel Bir Araştırma, İşletme Araştırmaları Dergisi, 13 (3), $2759-2779$ 
Discussion - Although there are studies on e-commerce web sites in the literature, the studies that evaluate the web page interfaces with qualitative data obtained from a real shopping process will contribute to the literature. This study is important in evaluating e-commerce site from direct customer views with user experience and a further interview. In line with the results of the study, various suggestions were made for the usability and improvement of web pages. In the light of these suggestions, it is expected that this study will contribute to businesses to gain competitive advantage, to create customer satisfaction, and to survive in digital environment.

\section{GİRIŞ}

İşletmeler müşterilerine İnternet üzerinden alışveriş imkânı sağlayan e-ticaret web sayfaları sayesinde zamandan ve mekândan bağımsız alışveriş imkânı sunmaktadır. Dijital yaşamın parçalarından biri olan elektronik ticaret (e-ticaret) sayesinde, satın almanın yanında mağaza gezintilerimizi yaptığımız, fiyat karşılaştırdığımız, indirim günlerini takip ettiğimiz ve hatta arkadaşlarımıza ürün önerisinde bulanabildiğimiz ortamlar sunulmaktadır. Bu faaliyetleri de barındıran e-ticaret kavramı alan yazında farklı şekillerde sınıflandırılmış ve tanımlanmıştır.

E-ticaret sayfalarının doğrudan etkileşim kurduğu müşterilerin gözünden değerlendirilmesi ve bu yönde yapılacak iyileştirmeler oldukça önemli görülmektedir. Geleneksel anlamda müşterilerin mağaza içindeki davranışları, yorumları, ürün kategorileri ve konumlandırmaları ile çeşitli düzenlemeler yapılmaktadır. Aynı şekilde e-ticaret web sayfası iyileştirmeleri de müşterilerin değerlendirmeleri sonucunda gerçekleştirilmelidir. Müşterileri karşılayan ana sayfa başta olmak üzere sayfa rengi, ürünlerin konumlandırılması ve ödeme sayfasına kadar e-ticarette gerçekleştirilen bütün iş ve işlemlerin değerlendirilmesi web sayfalarının daha etkili bir biçimde düzenlenmesine yardımcı olmaktadır.

Bu çalışma kapsamında da e-ticaret web sayfalarının müşteriler tarafından değerlendirilmesi ve bu konuda yapılabilecek iyileştirilmelere yönelik çeşitli önerilere değinilmiştir. Söz konusu değerlendirme gerçek eticaret web sayfası, gerçek müşteriler ve gerçek alışveriş süreci ile yapılmıştır. Kullanıcı deneyiminin ön planda olduğu bu araştırmada müşterilerle mülakat yapılmış, elde edilen veriler analiz edilmiş ve nitel bir araştırma yöntemi kullanılarak e-ticaret web sayfası değerlendirilmiştir.

\section{KAVRAMSAL ÇERÇEVE}

Çalışma kapsamında sunulacak olan kavramsal çerçevede e-ticaret, e-ticaret web sayfaları ve alanyazında yapılmış olan e-ticaret çalışmalarına değinilecektir.

\subsection{E-ticaret}

E-ticaret ile ilgili alanyazında da birçok tanımlama mevcuttur. Laudon ve Traver (2011) e-ticareti üreticiler ve tüketiciler arasındaki iş ilişkilerinin İnternet teknolojisi ve web sitesi kullanılarak gerçekleştirilmesi olarak ifade etmiştir. Başka bir tanımda ise mekân ve zaman olgularından bağımsız olarak her an her ortamda gerçekleştirilebilen alışveriş olarak görülmüştür (Akçi ve Annaç Göv, 2015). E-ticaret; iletişim, iş yönetimi, hizmet ve online perspektif kapsamında bilgi, ürün ve hizmetlerin İnternet üzerinden alım satım işleminin gerçekleştirilmesi olarak da tanımlanmaktadır (Whinston ve Kalakota, 1996). Bunların yanında birçok tanımı da ele almak mümkün olmasına karşın genel olarak vurgulanan noktalar derlendiğinde, e-ticareti; bireylerin üretici ve tüketici rollerinde zaman ve mekân kayması avantajı ile sanal ortamda bir araya gelerek mal, bilgi veya hizmet alışverişinin gerçekleştirildiği ticaret türü olarak tanımlayabiliriz. E-ticaretin gelişmesinin nedeni, temel olarak bilişim teknolojilerinin ilerlemesi ve piyasalardaki küreselleşme olarak görülse de bu gelişmeye neden olan birçok faktör bulunmaktadır. Müşteri odaklılık, tüketici tercihlerindeki değişim ve bilinçlenme, internette ürün seçebilme veya kıyaslama imkânı, örgütsel kültür değişimi ve müşteri ilişiklerinin değişmesi e-ticaretin gelişmesine neden olan faktörler arasındadır (Coşkun Karadă̆, 2005; Erserim, 2019). Bu gelişimin daha iyi anlaşılması için dünya ve Türkiye'de nasıl ilerlediğini incelemek daha doğru olacaktır.

E-ticaret kavramı ilk olarak EDI ( Electronic Data Interchange) ve EFT (Electronic Funds Transfer) teknolojilerinin ticari işlemleri kolaylaştırması sürecinde kullanılmış ve sonrasında birçok değişim göstermiştir (Hanson ve Kalyanam, 2006). Öyle ki bu değişim Türkiye verilerine de yansımıştır. 2009 yılında 10 milyar TL iken 2010 yılında 15 milyar TL'ye ulaşmış (Uygur, 2010), 2019 yılında ise 226 Milyar 210 Milyon TL'ye yükselmiştir (eticaret.gov.tr). E-ticaret bir bireysel müşterinin bir işletmeden yaptığı alış veriş olarak tanımlamak mümkün değildir. Taraflar açısından bakıldığında; işletmeler arası yapılan e-ticaret (B2B), tüketicilerin kendi aralarında yaptıkları e-ticaret (C2C), işletmeler ile tüketici arasında yapılan e-ticaret (B2C), 
işletme ile devlet arasında yapılan e-ticaret (B2G) ve son olarak vatandaş ile devlet arasında yapılan e-ticaret (C2G) türleri bulunmaktadır (Coşkun, 2019). E-ticaret söz konusu taraflar arasında çeşitli araçlar kullanılarak yapılmaktadır. Telefon, televizyon, EFT, EDI, İnternet, faks e-ticaretin yapılabilmesini sağlayan ana araçlar olarak kabul edilebilir. Gelecekte e-ticareti değiştirebilecek veya şekillendirebilecek aracın ne olacağı öngörülemezken, İnternet ile rekabet etmesi gerektiği önemli bir gerçektir (Yörük, 2001).

E-ticaret sürecinde taraflar arasında bir ilişki kurulmakta ve bu ilişki de çeşitli avantaj ve dezavantajlar ortaya çıkarmaktadır. Avantajlar arasında ilk olarak zaman ve mekân sınırlarının aşılması ve işlemlerde oluşan kolaylıklar ifade edilmektedir. E-ticarette ürün geliştirme, test etme, müşteri istek ve ihtiyaçlarının tespit edilmesi gibi avantajlar da firmalar tarafından arz ve talep ilişkisinin daha hızlı gerçekleşmesine neden olmaktadır (Erbaşlar ve Dokur, 2008). Bu avantajlarla birlikte başta finansal problemler olmak üzere yasal düzenlemelerle ilgili yaşanan sorunlar dezavantaj olarak görülmektedir. Dağıtılan bilgi üzerindeki denetimsizlik, verilerin sızması veya çalınması gibi dezavantajlar da bulunmaktadır.

\subsection{E-ticaret Web Sayfalarn}

Elektronik ticaretin gelişmesiyle birlikte kullanılabilirlik kavramı ve müşteri istekleri hayati önem taşımaktadır. Çünkü çevrimiçi bir tüketici, geleneksel bir tüketicinin tüm işlevlerini bir sanal ortamda gerçekleştirmektedir. Sanal ortamda işlem yapan bir tüketici, geleneksel tüketicinin tüm özelliklerini de sergilemektedir. Bir web sitesinde iyi tasarlanmış arayüzün ve uygun gezinmenin tüketiciler için geleneksel alışverişte düşük fiyatların ve iyi müşteri hizmetinin etkisi kadar önemli olduğu ifade edilmektedir (Koufaris, 2002). Geleneksel bir mağazanın satış elemanı ve fiziksel çevresi, çevrimiçi mağazadaki web sitesi tasarımı ve içeriğiyle eşleştirilmektedir (Lohse ve Spiller, 1998). Bu nedenle, iyi tasarlanmış bir e-ticaret web sitesi, organizasyon ile tüketici arasındaki etkileşimi kolaylaştırmaktadır (Montoya-Weiss, Voss, ve Grewal, 2003). Geleneksel ticarette yer alan mağazadaki bileşenler ile e-ticaret yapan bir firmanın web sitesi bileşenlerinin eşleştirilmesini özetleyecek olursak, satış temsilcisi; arama fonksiyonu, ürün açıklamaları veya online destek hizmeti olarak görülebilir. Mağaza vitrini sitenin ana sayfası olarak görülürken mağaza ortamı ve kat sayısı arayüz tutarlılı̆̆ ve hiyerarşik seviyeler olarak ifade edilebilir. Diğer taraftan ürüne bakma faaliyeti için site içerisinde sınırlı resim kalitesi ve açıklamaları, ses ve video uygulamaları yer almaktadır. Mağazaya giriş yapan kişi sayısı ise siteyi ziyaret eden ziyaretçi sayısı ile eşleştirilmiştir (Lohse ve Spiller, 1999).

İster geleneksel ister sanal ortamda ticaret yapan işletme olsun hepsinin en değerli varlığ şüphesiz müşterileridir. Her işletme bu kıymetli varlığı kaybetmemek ve hatta mevcut müşterileri korumak için çeşitli stratejiler geliştirmektedir. Özellikle e-ticaret şirketlerinin müşteri kaybetmeleri veya kazanmaları site tasarımı ve kullanım kolaylığı ile doğrudan ilişkilidir. Müşteri merkezli bir web sitesi içerik, verim, marka değeri, memnuniyet gibi özelliklere sahip olmalıdır (Van Duyne, Landay, ve Hong, 2003). Online alışveriş sitelerinin kârını düşüren en önemli neden ise kötü tasarlanmış bir web sayfası olarak görülmektedir (Nielsen, 2002).

\subsection{Alanyazında E-ticaret Çalışmalan}

Alanyazında e-ticareti konu edinmiş birçok çalışma bulunmaktadır. Fakat bu çalışma kapsamında e-ticaret web sayfalarını ele alan çalışmalara yer verilmiştir. E-ticaret web sayfası çalışmalarında odaklanılan konular güvenlik, müşteri sadakati, memnuniyet, tasarım, müşteri sınıfları başlıkları altında sınıflandırılabilir. Müşterilerin demografik özelliklerinin de e-ticaret işletmeleri için önemli olduğu ifade edilen çalışmalar da bulunmaktadır. Örneğin, Akçi ve Annaç Göv (2015) çalışmalarında müşterilerin yaş, cinsiyet, eğitim seviyesi, meslek ve gelir durumları ile e-ticaret algıları arasında önemli bir farklılık olduğunu ifade etmiştir. Akyazı (2018) ise e-ticaret sitelerini incelerken yaş demografik etkenini ele almıştır. E-ticaret web sayfaları hazırlanırken sadece gençlere yönelik tasarımın yapılmasını ve yaşlı bireylerin bu konuda göz ardı edilmesi üzerinde durulmuştur. İyi tasarlanmış bir e-ticaret sayfasının bütün yaş gruplarına hitap etmesi gerektiği de ifade edilmiştir. Bu amaçla ödeme yöntemi alternatiflerinin sunulması, ürün bilgilerinin detaylandırılması, renklendirmelere dikkat edilmesi, yazı tiplerine önem gösterilmesi gibi unsurlar yaşlı bireylerin internetten alışveriş yapmasını kolaylaştıracağı ifade edilmiştir. Müşterilerin cinsiyete göre e-ticaret platformlarındaki ürün arama sürecinde ihtiyaçlarını anlamak için e-ticaret kullanımının incelendiği araştırmada ise her iki cinsiyetin ihtiyaçlarının birbirine benzediği ifade edilmiştir. Çalışma kapsamında ürüne özel filtreleme ve sıralama gibi ürün arama desteğinin olmaması sorun olarak aktarılmıştır. Ayrıca web siteleri site içi bir arama motoru sunsa da, kullanıcılar çeşitli şekillerde arama yapma eğiliminde olduklarından iyi yapılandırılmış bir kategori ve alt kategori yapısının uygulanması gerekliliği önerilmiştir (Öztürk, 2019). Demografik faktörlere 


\section{E. Özmen - E. Karaman - N. Alkış 13/3 (2021) 2759-2779}

odaklanan Erserim (2019) de kuşaklar arasında e-ticarete yönelik tutumları incelediği çalışmasında zaman tasarrufu, geniş bilgi yelpazesi, pratik ve kolay alışveriş, maliyet avantajı, marka takibi ve güven odaklı unsurları $\mathrm{Y}$ ve $\mathrm{Z}$ kuşaklarının daha çok benimsediğini bulmuştur. Bu unsurları en az benimseyen kuşakların ise bebek patlaması ve $X$ kuşağı olduğunu ifade etmiştir.

Mohd ve Zaaba (2019) yaptıkları çalışmada 2000 ve 2018 yılları arasında e-ticaret web sitesinin kullanılabilirliğini ve güvenliğini değerlendirmek için geliştirilen modelleri incelemiştir. Kullanılabilirlik ve güvenliğin tüm boyutlarını birbirine bağlayan kapsamlı bir modelin olmadığını ifade etmişlerdir. Modellerin çoğu, yalnızca birkaç kullanılabilirlik boyutuna odaklanmış ve temel olarak öğrenilebilirlik, memnuniyet ve kullanışlılık gibi boyutlara vurgu yapmıştır. Geliştirilen modellerde güvenlik ve gizlilik sorunları gibi faktörlerin göz ardı edildiğini aktarmışlardır. İnternet sitesi tasarımının müşterilerin güveni, memnuniyeti ve satın alma niyetleri üzerine etkisinin araştıııldığı bir çalışmada ise doğru, açık ve güvenilir bilgilerin tüketici güveni ve satın alma davranışı üzerine bir etkisi olduğu ifade edilmiştir. Ayrıca etkili ve doğru bir sayfa tasarımının işletmelere satış başarısı ve rekabet avantajı da sağladığı söylenmiştir (Alhussein ve Atılgan, 2021). Ülger ve Toksarı (2020) ise çalışmalarında e-ticaret web sayfası tasarımın güven-memnuniyet ile ilişkisinin olduğu ve satın alma davranışını etkilediğini belirtmiştir. Bu yüzden işletmelerin e-ticaret sayfa tasarımına özen göstermelerini, tüketici kaybını önlemek için yetersiz bilgi ve yanlış yönlendirmelerden kaçınmaları gerektiğini ifade edilmiştir. Müşterilerin zaman kaybı yaşamamaları istedikleri ürüne hızlı ulaşmaları açısından da web sayfası tasarımının önemi vurgulanmıştır.

Gürsel (2019) başarılı bir e-ticaret web sitesinin anahtarı olduğunu açıklığa kavuşturmak için derinlemesine görüşme yapmış ve kullanıcıların bir markanın e-ticaret sayfası tasarımının, işlem yapma kararlarını etkileyen en önemli faktörlerden biri olduğunu ifade etmiştir. E-ticaret siteleri kullanıcı deneyiminde tasarım ve işlevsellik vurgulanmış, kullanıcı deneyimi çalışmalarının e-ticaret dönüşüm oranlarının artırmasına ve başarılı olmalarına olanak tanıdığı aktarılmıştır. E-ticaret sektöründeki şirketler kullanıcı deneyim çalışmaları için dijital pazarlama ajanslarında çalışan uzmanlardan danışmanlık almasının ya da şirket içinde ekipler kurulmasının pazarda kalıcılığı ve rekabet avantajı sağlayacağı önerisinde bulunulmuştur. Xu ve Zhang (2019) ise E-ticaret sitelerinde renk faktörünü ele almış ve tasarımcıların renkli etiketlerin rengini (kırmızı veya yeşil) ve bu etiketlerin anlamını (pozitif veya negatif) e-ticaret web sitelerinde daha tutarlı bir şekilde ifade etmeleri gerektiğini aktarmışlardır. Negatif anlamlı yerlerde kırmızı pozitif anlamlı noktalarda ise yeşil renk kullanılmasını ifade etmişlerdir. Başka bir çalışmada ise web sitelerinin ana sayfası kullanıcı için giriş noktası olduğundan, kullanılabilirlik ve erişilebilirlik için iyileştirmeler için birincil hedef olması gerektiği vurgulanmaktadır. Web sitelerinin sürekli olarak iyileştirilmesinin, kullanıcı deneyimini geliştirdiği ve kişilerin yaşayabileceği dijital uçurumun azalttığ web sayfaları ile ilgili yapılan başka bir çalışmada ise web sayfalarının kalitesi, potansiyel tüketicileri cezbetmede, ilk kez satın almaları teşvik etmede ve tekrar satın almaları elde tutmada önemli bir faktör olduğu aktarılmıştır. E-ticaret web sayfasının kalitesinin, tüketiciler için en çok tercih edilen e-ticaret web sitesini seçmede önemli bir bileşen olduğu ve sonuçta hizmet sağlayıcılar için daha fazla gelir sağladığı vurgulanmıştır (Sharma ve Lijuan, 2015). Müşterilerin e-ticaret ortamında satın alma karar sürecine yönelik bilimsel temelli yaklaşım ortaya koyan bir diğer çalışmada ise farklı ülkelerden katılım sağlayan 16 kadın katılımcı ile mülakat yapılmıştır. Kullanışlılık, erişilebilirlik, hız, rahatlık ve kolaylık gibi faktörler kapsamında tüketicilerin satın alma karar süreçlerindeki benzerlikler ve farklıklar tespit edilmiştir (Gürbüz, Ayaz ve Albayrak, 2015).

Alan yazındaki çalışmalardan hareketle gerçek bir alışveriş sürecinin tasarlanması, kullanıcı deneyiminin oluşturulması, gerçek kullanıcılar tarafından e-ticaret web sayfalarının nitel değerlendirme ile ele alınması gibi konularda yeni çalışmalara ihtiyaç duyulduğu anlaşılmaktadır. Bu çalışmada ise e-ticaret sayfalarında kullanıcıların keşfetme, ürün arama-bulma ve satın alma süreçleri nitel olarak incelenmiştir. Müşteriler ile eticaret sayfası arayüzünün kullanılabilirlik değerlendirilmesi mülakat tekniği ile yapılmış ve "demografik faktörlerin e-ticaret web sayfası değerlendirmesinde bir etkisi var mıdır?" araştırma sorusuna cevap aranmıştır. Bu araştırma sorusu kapsamında ana sayfa görünümü, gerçekleştirilen görevler, siteyi tekrar kullanım durumu, reklam farkındalığı, beğeni durumu gibi unsurlarda ki değerlendirme farklılıklarının olup olmadığı da alt araştırma sorusu olarak ele alınmıştır. 


\section{YÖNTEM}

$\mathrm{Bu}$ çalışmada işletmelerin dijital ortamda var olmalarını sağlayan e-ticaret sitelerinin kullanılabilirliğini değerlendirme amaçlanmıştır. Bu amaç doğrultusunda kullanıcıların bir alışveriş sürecinde keşfetme, ürün arama-bulma, satın alma gibi aşamalarda müşteri görüşlerini ele alarak nitel bir değerlendirme yapılmıştır.

\subsection{Evren ve Örneklem}

Çalışmanın evrenini e-ticaret sitesi üzerinden alışveriş süreci adımlarını gerçekleştiren müşteriler oluşturmaktadır. Çalışma kapsamında örneklem grubu amaçsal örnekleme yöntemlerinden olan maksimum çeşitlilik örnekleme yöntemi ile belirlenmiştir (Büyüközktürk vd., 2014; Patton, 1990). Örneklem; X, Y, Z kuşak gruplarından Lise, Ön lisans-Lisans ve Lisansüstü (Yüksek lisans-Doktora) eğitim sınıflarına ait kadın ve erkek 32 katılımcıdan oluşmaktadır. Kuşak sınıfları 1965-1979 yılları arasında doğan bireylerin X, 1980-1999 yılları arasında doğanların $\mathrm{Y}$ ve 2000 yılı ve sonrasında doğan bireylerin de $\mathrm{Z}$ kuşağı olarak belirlenmiştir (Erer, 2020).

\subsection{Veri Toplama Araçları}

Araştırma kapsamında nitel verilerin toplanması için deney sonrasında uzman görüşü, site yöneticileri ve alanyazın araştırmasından hareketle hazırlanmış açık uçlu 8 sorudan oluşan yapılandırılmamış bir ölçek kullanılmıştır. Katılımcılardan; e-ticaret sitesinin ana sayfası hakkında görüşleri, gerçekleştirdikleri görevler hakkında yorumları, site hakkında genel düşünceleri gibi soruları cevaplamaları istenmiştir. Görüşme formu yaklaşımı benimsenerek gerçekleştirilen mülakatla deney süreci ile ilgili tüm boyutların ve soruların kapsanmasını güvence altına almak amaçlanmıştır (Yıldırım ve Şimşek, 2016). Görüşme yönteminin kullanılması esneklik, yanıt oranı, sözel olmayan davranış, anlık tepki, teyit gibi avantajları bakımından oldukça önemlidir (Bailey, 1982).

\subsection{Deney Süreci}

Gönüllülük beyanı alınan ve deney hakkında bilgilendirilen katılımcılardan katılımcı bilgi formunu doldurmaları ve sonrasında ana sayfada gezinim görevi ile alışveriş sürecine başlamaları istenmiştir. . Katılımcı sırasıyla; üyelik oluşturma, belirlenen miktar tutarında bir ürünü sepete ekleme, aynı fiyat aralığında iki tane daha alternatif ürün bulma ve sepete ekleme, karar sürecinde bulunma ve karar verme görevlerini gerçekleştirmiştir. Sonrasında satın alma işleminin gerçekleştirilmesi, indirim kuponu girme, iletişim bilgilerinin doldurulması ve çalışma kapsamında belirlenen sanal bir kredi kartı bilgilerinin girilmesi görev aşamalarını tamamlamıştır. Tam anlamıyla gerçek bir alışveriş sürecini tamamlayan katılımcımıza satın aldığ 1 ürün çalışma kapsamında hediye edilmiştir.

\subsection{Veri Analizi}

Çalışmada alışveriş süreci sonrasında görüşme formu ile toplanan nitel veriler MAXQDA 2020 yazılımı kullanılarak analiz edilmiştir. Analiz sürecinde toplanan verilerin kavramsallaştırılması, mantıksal bir biçimde düzenlenmesi ve verileri açıklayan temaların saptanması amaçlanarak içerik analizi yapılması uygun görülmüştür (Yıldırım ve Şimşek, 2016). Görüşme formu içerik analizini temel olarak dört aşamada özetleyebiliriz. Analizin ilk aşamasını verilerin kodlanması oluşturmaktadır. Bu aşamada veri seti tekrar tekrar okunmuş ve katılımcıların verdiği cevaplar doğrultusunda her bir soru için ne söylenmek istendiği belirlenerek genel ifadeler oluşturulmuştur. Bütün katılımcıların verileri kodlandıktan sonra bir kod listesi ortaya çıarılmıştır. Strauss ve Corbin (1990) tarafından öne sürülen veri kodlama türlerinden "verilerden çıkarılan kavramlara göre kodlama" türü esas alınmış ve tümevarım yaklaşımı benimsenmiştir. Söz konusu kodlar kurgulanırken gerek fiziksel gerekse zihinsel olarak yoğun ve yorucu bir süreç olduğundan iki nitel araştırma uzmanı tarafından ayrı ayrı kodlar oluşturulmuş ve nihai kod listesi fikir birliğine varılarak şekillendirilmiştir. Söz konusu uzmanlardan biri veri toplama ve deney sürecinde yer alırken diğer uzman bu süreçlerin hiçbirinde bulunmamış ve tamamen bağımsız olarak kodlamada yer almıştır. Uzmanların kodlamada iki farklı şekilde bulunması kodlayıcılar arası uzlaşmanın tarafsızlık ve tutarlılık ilkeleri gözetilerek gerçekleşmesini sağlamıştır.

İçerik analizinin ikinci aşamasında temaların bulunması sağlanmıştır. Kodlardan yola çıkarak bunları genel olarak açıklayabilen ve tek bir başlık altında kategorilendirmeyi sağlayan ifadeler bulunmaya çalışılmıştır. Bu aşamaya kısaca tematik kodlama adımı da diyebiliriz. Tematik kodlama yapılırken iç ve dış tutarlılık dikkate 


\section{E. Özmen - E. Karaman - N. Alkış 13/3 (2021) 2759-2779}

alınmıştır. Üçüncü aşamada ise veriler kodlara ve temalara göre düzenlenerek tanımlanmıştır. Yani katılımcılardan elde edilen veriler okunarak ilgili temaya ve koda alınarak sınıflandırılmıştır. Bu sınıflandırma yapılırken araştırmacı herhangi bir görüş ve yorum eklemekten kaçınmış katılımcı cevabını doğrudan koda ya da temaya taşımıştır. Sınıflandırmalarda "Hiyerarşik Kod-Alt Kod Modeli" kullanılarak bir ağaç yapısı elde edilmiştir. Son olarak tanımlanan verilerden kod frekansları, alt kod sınıflandırmaları ve diğer bulgular çıkarılarak yorumlama yapılmıştır. Katılımcıların bütün görüşlerinden yola çıkılarak bir "kelime bulutu" hazırlanmış ve söz konusu e-ticaret sayfasında öne çıkan düşünce ve yorum kavramları özetlenmeye çalışılmıştır.

\subsection{Araştırmacıların Rolï}

Çalışmada araştırmacıların rolü deney sürecini kurgulama ve gerçekleştirme, örneklem grubuna ulaşma, veri toplama, veri düzenleme, geçerlilik ve güvenilirlik çalışmalarını yapma, verileri analiz etme ve raporlamadır. Verilerin analiz edilmesinde gerek alanyazın taraması gerekse akademik ve alan uzmanlarının yardımıyla veri analizini gerçekleştiren araştırmacılar bulguları elde etmiş ve raporlamıştır. Sonrasında bulgulara dayalı sonuçlar sunan araştırmacı alana yönelik çeşitli önerilerde bulunmuştur.

\subsection{Geçerlilik ve Güvenilirlik}

Verilerin analizi kapsamında geçerlilik ve güvenilirlik konusunda, veri toplama ve analiz tekniklerinin arasındaki uyum, ifadenin anlaşılabilirliği, yorumlama da yetkinlik ve uyarlanabilirlik gibi ölçütler dikkate alınmıştır (Arastaman, Fidan ve Fidan, 2018). Söz konusu ölçütlerin varlığı niteliği artırmış, inandırıcılıkla birlikte betimsel, yorumlayıcı ve kuramsal geçerliliği sağlamıştır (Maxwell, 1992; Whittemore, Chase ve Mandle, 2001).

\subsection{Etik Çerçeve}

$\mathrm{Bu}$ çalışma bilimsel etik kapsamındaki kurallara sadık kalınarak yürütülmüştür. Araştırma konusu özgün olarak seçilmiş ve deney süreci bu özgünlükte tasarlanmıştır. Gerçeğe uygunluk, bilimsel araştırma sürecinde herhangi denek veya ortama zarar vermeme, kaynak gösterme ve alıntılar başta olmak üzere tüm bilim etiği ilkeleri göz önünde bulundurularak araştırma tamamlanmıştır (TÜBA, 2002; Ortaş, 2010). Veri toplama sürecinin gerçekleştirilmesi ve araştırmanın yürütülmesi kapsamında Atatürk Üniversitesi Sosyal ve Beşeri Bilimler Etik Kurul Başkanlığından onay alınmıştır. Çalışmada incelenen e-ticaret sitesi yöneticileri ile görüşülmüş ve değerlendirme izni alınmıştır. Katılımcıların araştırmaya gönüllü olarak katıldıklarını gösteren gönüllülük beyanları alınmıştır. Örneklem grubunun $\mathrm{Z}$ kuşağında yer alan 18 yaş altındaki katılımcıların velilerinden veli izin beyanı alınmıştır. Araştırmadaki veriler bilimsel yöntemlerin dışına çıkılmadan analiz edilerek yorumlanmış üçüncü kişi veya kurumlarla paylaşılmamıştır.

\section{BULGULAR}

E-ticaret sayfası üzerinden gerçek bir alışveriş sürecini tamamlayan katılımcılarla yapılandırılmamış 8 soruluk bir görüşme gerçekleştirilmiştir. Görüşmede yer alan sorulardan 6 farklı tema belirlenmiş ve bunların alt kodları oluşturulmuştur. Tema ve kodlara yönelik oluşturulan kod ağaçları, katılımcı görüşleri, görüş sıklıkları sırasıyla bu başlık altında sunulacaktır. 32 katılımcıya ait alışveriş süreci ile ilgili görüşme formları okunmuş ve uzmanların fikir birliği sonucunda oluşturulan temalarla birlikte belirtilen görüş sayısı Şekil 1' de sunulmuştur. 


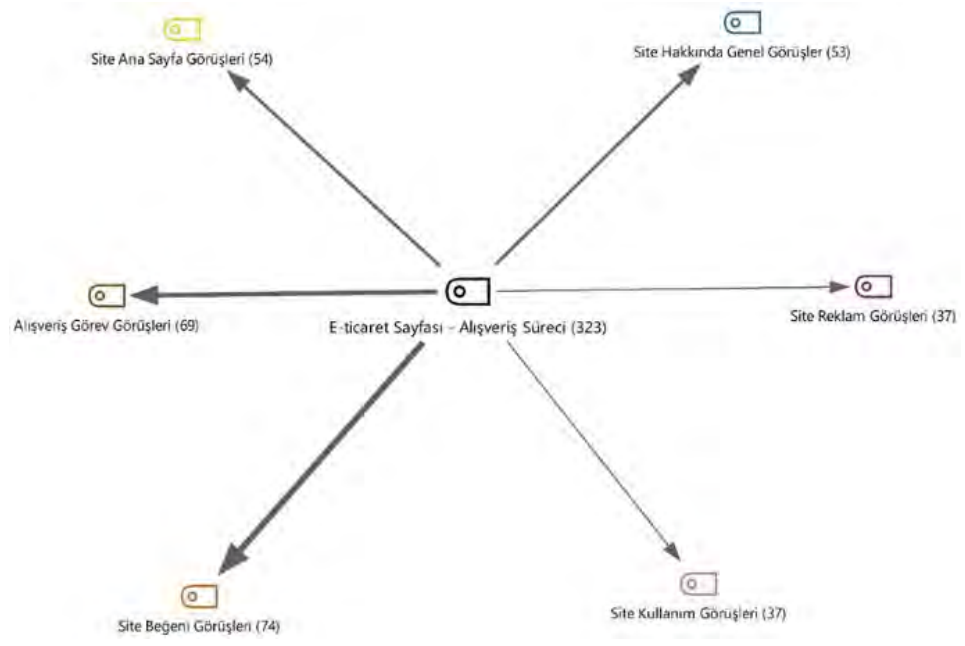

Şekil 1. Katılımcı Görüşmeleri Sonucunda Oluşturulan Temalar

Şekil 1'de görüldüğü üzere 32 katılımcı ile gerçekleştirilen görüşme sonucunda 6 ana tema oluşturulmuştur. Bu temalar; site ana sayfa görüşleri, site hakkında genel görüşler, site reklam görüşleri, site kullanım görüşleri, site beğeni görüşleri, alışveriş görev görüşleri olarak adlandırılmıştır. E-ticaret sayfası ve alışveriş süreci hakkında toplamda 323 anlamlı görüş belirtilmiştir. Bu görüşlerin çoğunluğunu site hakkındaki beğeni durumları oluştururken site kullanımı ve site reklam temaları en az görüş alınan tema olarak belirlenmiştir. Belirlenen temalara yönelik veri kodlamaları gerçekleştirilmiştir. Şekil 2'de site ana sayfa görüşleri temasına yönelik oluşturulan kodlar ve görüş dağılımları sunulmuştur.

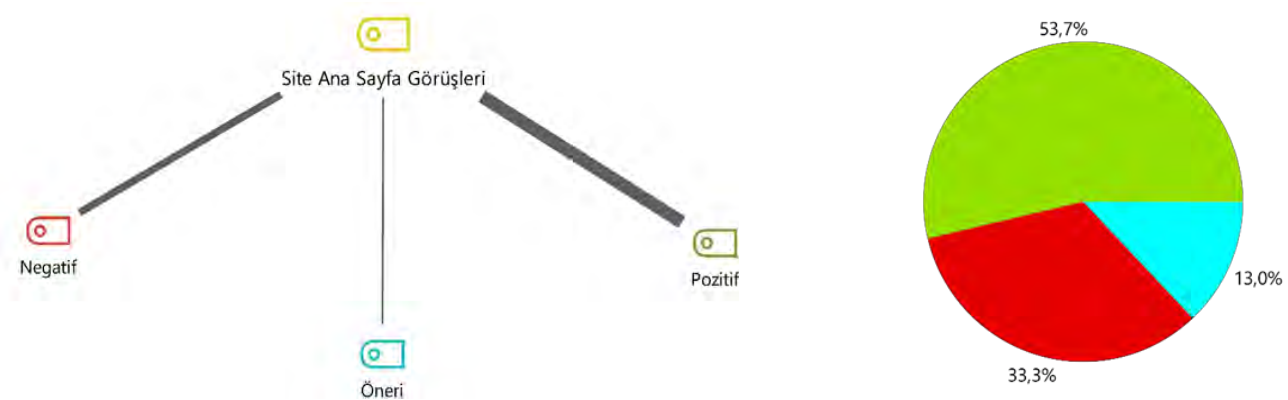

Şekil 2. Site Ana Sayfa Görüş Kodları ve Dağılımları

Site ana sayfa görüşleri teması için yapılan analizler sonucunda katılımcıların negatif, pozitif ve öneri görüşleri bildirdikleri görülmüştür. Katılımcıların e-ticaret sitesi ana sayfası hakkındaki görüşlerinin \%53.7 (29)'si pozitif anlam belirtirken \%33,3 (18)' ü negatif olarak değerlendirilmiştir. Diğer görüşler (\%13(7)) ise ana sayfa hakkında öneri niteliği taşımaktadır. Tablo 1'de katılımcı görüşlerinden çıkarılan ortak kod yorumları ve katılımcı bilgileri sunulmuştur. Katılımcılar kodlanırken ilk karakter kuşă̆ı, ikinci karakter cinsiyeti, üçüncü karakter eğitim durumunu ve dördüncü karakter sırasını bildirmektedir. Örneğin X kuşağındaki, erkek ve lise mezunu birinci katılımcı “XEL1" olarak kodlanmıştır. Bulguların tamamında bu isimlendirme uygulanmıştır.

Tablo 1. E-ticaret Sitesi Ana Sayfası Katılımcı Görüşleri

\begin{tabular}{lll}
\hline Katılımcılar & Görüş & Kod \\
\hline XEL1, XKL1, & & \\
XKL2, XEÜ1, & & \\
XEÜ2, XKÜ1, & “Ürün görselliği ve menüler güzeldi. Kullanılan renk ve sayfa niteliği uyumluydu. & Pozitif \\
XKLÜ1, & Ürün kategorilendirmeleri açı, net ve sade şekilde... Menüler kolay ve anlaşıllr...” & \\
XKLÜ2, & & \\
XELÜ2 &
\end{tabular}


YEL1, YKL2,

YKÜ2, YEÜ1, "Ana sayfa karmaşık değildi. Sitenin içeriği kullanılan renklerle belli oluyordu...

YEÜ2, Görsel olarak çok güzel hazırlanmış... Basit ve kullanılabilirdi. Renkler

YKLÜ1, uyumluydu..."

YELÜ2

ZEL1， ZEL2,

ZKL1, ZKL2,

ZEÜ1, ZEÜ2

ZKÜ1

"Tasarm ve renklendirme güzel. Herkese hitap ediyor. Çok sade ve gözü yormuyordu... Basit ve kullanulabilirdi. Herkesin kullanabileceğgi bir tasarımı Pozitif vardl..."

XEL2, XKL1,

“Karmaşık görünüyor. Resimler çok küçük. Çoğu ürünün resmini görmek için XKÜ2, XEÜ1, XELÜ1

sayfanın aşağısına inmek gerekiyor...

Ana sayfada güven veren bir bilgi yok. Ürün açıklamaları ve yönlendirmeler yoktu... Açıkçası karışık..."

YEL2, YKL1,

YKÜ1, YKÜ2, "Profesyonel olmayan, basit bir şekilde yapılmış bir ticaret sayfası... Ürünlerin YELÜ1, dağılımı karışık... Resim olması ve rengin yeşil olması çok yorucu. Ürün YELÜ2, $\quad$ özelliklerini göremediğim için zaman kaybı yaşadım. Ana sayfa kalabalık ve renkler Negatif YKLÜ1, göz alıcrydı. Karışıktı..."

YKLÜ2

ZEÜ1, ZKÜ2 "Ana sayfa kullanışlı değil... Ana sayfayı beğenmedim."

Negatif

XEÜ2, XKLÜ1

"Daha iyi olabilir. Sadece daha sicak renkler kullanılması gerektiğini düşünüyorum..."

Öneri

ZEL2, ZEÜ1,

"Renklendirmede arka plan daha koyu olabilir. Biraz daha kullanışl olabilir...

ZKÜ2 İndirimli ürünler varsa onlar ön plana çıkarllabilir. Daha farklı olabilirdi... Tüm Öneri ürünlere dair bilgiler sunulabilirdi."

Tablo 1'de görüldüğü üzere katılımcllar ana sayfa hakkında kategori, menü, görsellik ve sadelik gibi noktalarda pozitif yorumlar yaparken renk, ürün konumlandırma, resimler, basitlik, ürün bilgilendirmeleri gibi bölümlerde ise negatif görüşler sunmuşlardır. Ana sayfa ile ilgili özellikle renklendirme için öneride bulunmuşlardır. Katılımcıların kuşak faktörü üzerinden yapılan değerlendirmede ise pozitif görüşlerin çoğunluğunu X kuşağı katılımcıları oluştururken negatif görüşlerin çoğunluğunu Y kuşağı katılımcıları oluşturmuştur. Site ana sayfası ile ilgili $X$ ve $Z$ kuşağı öneride bulunurken $Y$ kuşağı herhangi bir öneri görüşünde bulunmamıştır.

Katılımcıların gerçekleştirdikleri alışveriş sürecinde onlara verilen görevler bağlamında sorular yöneltilmiştir. Alışveriş Görev Görüşleri teması altında belirlenen kodlar ve onlara ait alt kodlar Şekil 3'de sunulmuştur. 


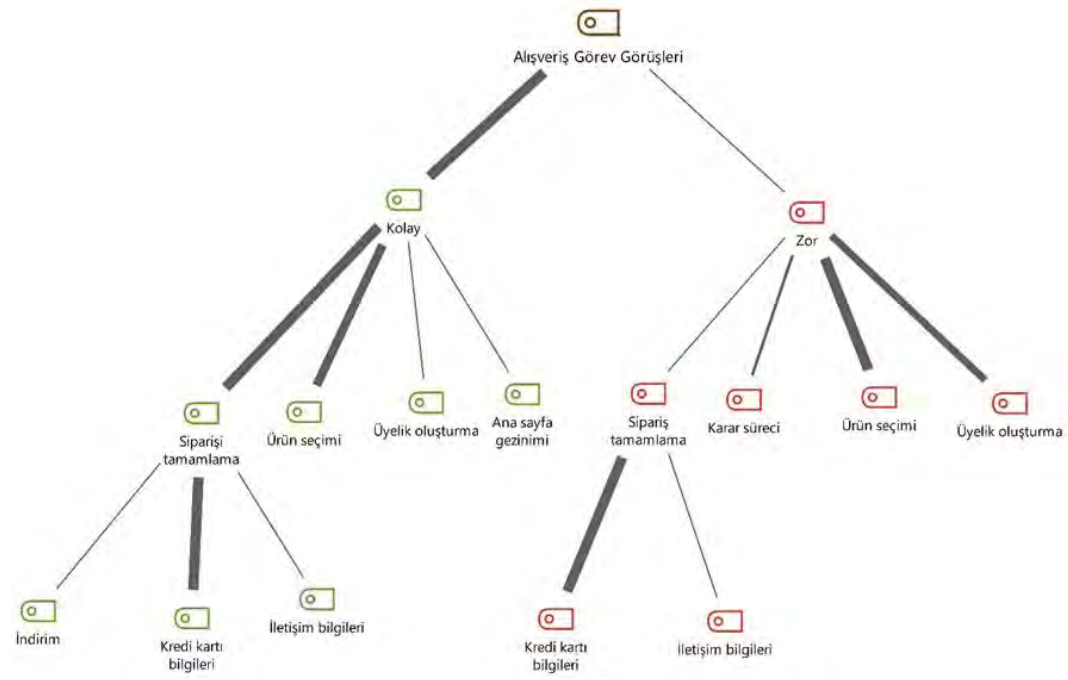

Şekil 3. Alışveriş Görev Görüşleri Kodları

Alışveriş görev görüşleri teması altında katılımcıların ifade ettikleri görüşler doğrultusunda kolay ve zor olmak üzere iki ana kod belirlenmiştir. Kolay ana kodu çerçevesinde sipariş tamamlama, ürün seçimi, üyelik oluşturma, ana sayfa gezinimi alt kodları oluşturulmuş ve sipariş tamamlama alt kodu için indirim, kredi kartı bilgileri ve iletişim bilgileri ikinci seviye alt kod oluşturulmuştur. Zor ana kodu kapsamında sipariş tamamlama, karar süreci, ürün seçimi ve üyelik oluşturma alt kodları belirlenmiştir. Sipariş tamamlama alt kodunda kredi kartı bilgileri ve iletişim bilgileri olmak üzere iki adet ikinci seviye alt kodları oluşturulmuştur. Katılımcıların alışveriş görev görüşleri kod dağılımları Şekil 4'de sunulmuştur.
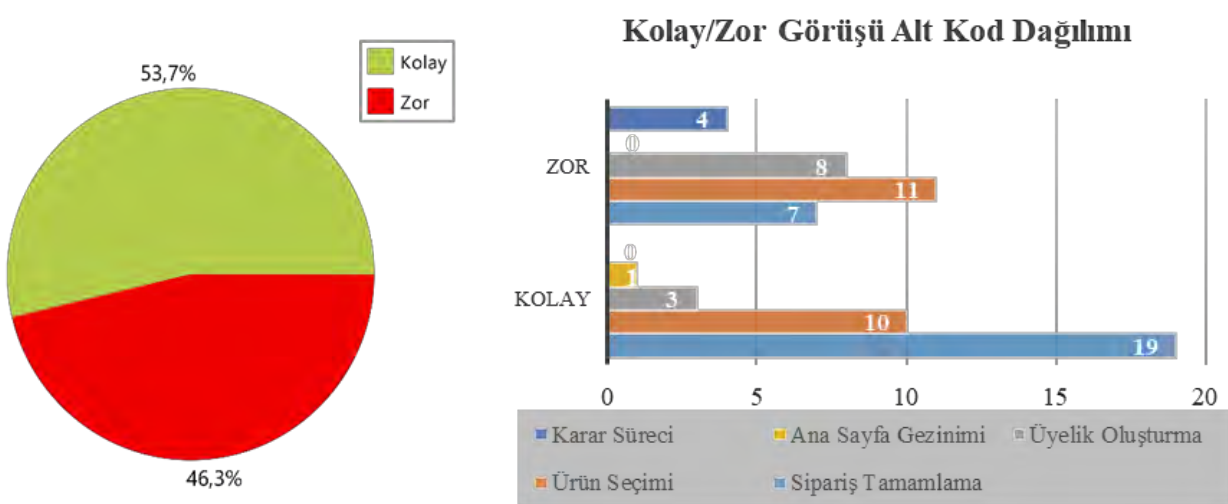

Şekil 4. Katılımcıların Alışveriş Görevleri Hakkındaki Görüş Dağılımları

Şekil 4 incelendiğinde katılımcılar alışveriş sürecinde verilen görevlerde \%53,7 (37) kolay görüş belirtmişken görevlerin zor olduğunu bildiren görüşler $\% 46,3$ (32) oranındadır. Bu görüşlerden hareketle katılımcıların en kolay gerçekleştirdikleri görev sipariş tamamlama \%57,6 (20) olarak görülmektedir. Katılımcılar en çok zorlandıkları görev bölümünün üyelik oluşturma ve sipariş tamamlama görevindeki kredi kartı bilgilerinin girişi \%25,8 (8) olduğunu belirtmişlerdir. Bu görüşler doğrultusunda katılımclların alışveriş görevlerinde oluşturulan alt kodlara katılım yorumları ve katılımcı bilgileri Tablo 2' de sunulmuştur. 
E. Özmen - E. Karaman - N. Alkış 13/3 (2021) 2759-2779

Tablo 2. E-ticaret Sitesi Alışveriş Görevleri Katılımcı Görüşleri

\begin{tabular}{|c|c|c|}
\hline Katılımcılar & Görüş & Kod \\
\hline $\begin{array}{l}\text { XEL2, XKL1, } \\
\text { XKÜ1, XKÜ2, } \\
\text { XEÜ1, XEÜ2, } \\
\text { XELÜ1, } \\
\text { XELÜ2, } \\
\text { XKLÜ1, } \\
\text { XKLÜ2 }\end{array}$ & $\begin{array}{l}\text { “Siparişi tamamlamak en kolay görevdi... Indirim kuponu girmekte zorluk yaşamadım... } \\
\text { Satın almak daha kolaydı. Ürün seçmek ve sepete eklemek ve alışverişi sonlandırmak } \\
\text { kolaydı... }\end{array}$ & Kolay \\
\hline $\begin{array}{l}\text { YEL1, } \\
\text { YEL2, } \\
\text { YKL1, } \\
\text { YEÜ1, } \\
\text { YEÜ2, } \\
\text { YKÜ1, } \\
\text { YELÜ2, } \\
\text { YELÜ2, } \\
\text { YKLÜ1, } \\
\text { YKLÜ2 }\end{array}$ & $\begin{array}{l}\text { "Ürün seçimi kolaydı.... Alışverişi tamamlamak kolaydı. Herhangi bir zorluk yaşamadım. } \\
\text { Genel olarak kolaydı... Alışverişi tamamlama bölümü kolaydı. Siparişimi eklemek } \\
\text { kolaydı..." }\end{array}$ & Kolay \\
\hline $\begin{array}{l}\text { ZEL1, } \quad \text { ZEL2, } \\
\text { ZKL1, ZKL2, } \\
\text { ZEÜ1, ZEÜ2, } \\
\text { ZKÜ1, ZKÜ2 }\end{array}$ & $\begin{array}{l}\text { "Ürünleri sepete eklemek ve siparişi tamamlamak kolaydı. Gezinti, üye olmak ve alışverişi } \\
\text { tamamlamak kolaydı.... Siparişi tamamlamak ve iletişim bilgilerini girmek kolaydı.." }\end{array}$ & Kolay \\
\hline $\begin{array}{l}\text { XKL1, XKL2, } \\
\text { XEÜ1, XEÜ2, } \\
\text { XKÜ1, XKÜ2, } \\
\text { XKLÜ2, } \\
\text { XELÜ1, } \\
\text { XELÜ2 }\end{array}$ & $\begin{array}{l}\text { "Tüm kategoriler arasında ürünü bulmak zordu. Herhangi bir ayrım göremedim... Kart } \\
\text { bilgileri girmek ve üye olmak oldukça zordu... Üye olma ve üye giriş yeri aynı } \\
\text { sayfadaydı... Telefon numarasını girerken sıfır yazılması gerekiyor mu belli değildi tekrar } \\
\text { girip kontrol ettim. Adres girerken adres başlı̆̆ı ne demek açıklaması yoktu... Alışverişi } \\
\text { bitirme noktası zordu... Kart görseli yeni kullanılmaya başladı̆̆ı için sıkıntı yaşadım... } \\
\text { Üye olma işlemi çok sıkıcıydı... Kart bilgilerini girmek çok zordu..." }\end{array}$ & Zor \\
\hline 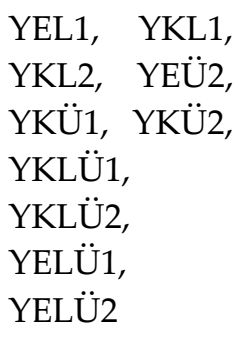 & $\begin{array}{l}\text { "Üye olmak zordu. Fiyat aralığında filtreleme olmadı̆̆ı için zorlandım. Üye giriş } \\
\text { sekmesine girildiği zaman direkt beni yönlendirmesi gerekirdi. Üye olma ve üye girişi } \\
\text { farklı olmalıydı.... Ürün elemek zordu. Ürünler arasında seçim yapmakta zorlandım. } \\
\text { Yanlarında herhangi bir buton yoktu..." }\end{array}$ & Zor \\
\hline $\begin{array}{l}\text { ZEL1, } \quad \text { ZEL2, } \\
\text { ZKL1, ZKL2, } \\
\text { ZKÜ1, ZKÜ2, } \\
\text { ZEÜ1 }\end{array}$ & $\begin{array}{l}\text { "Kredi kartı bilgilerini doldurmak biraz daha zordu. Nedeni ise alışık olmadı̆̆ım bir } \\
\text { durum olması.... İtal edeceğim ürünlerde belirgin olmayan bir çarpı işareti olduğu için } \\
\text { zorlandım. Son aşama çok fazla zamanımı aldı zorlayıcıydı. Sepetten ürün çıkarmak } \\
\text { zordu... Üye girişi zorladı. Ürün bulmak zor oldu..." }\end{array}$ & Zor \\
\hline
\end{tabular}

Katılımcıların görüşleri incelendiğinde en kolay görev/ler kapsamında; siparişin tamamlanması, ürün seçimi gibi ifadeler yer alırken en zor görev/ler için üye olmak, kredi kartı bilgilerini girmek, alışverişi sonlandırmak ifadeleri yer almaktadır. X, Y ve Z kuşağında bulunan katılımcılar görevlerin zorluk ve kolaylık seviyeleri ile ilgili görüş belirtirken kolay olarak nitelendirdikleri görevlerde hem fikir oldukları görülürken zor görevlerle ilgili farklı noktalara değinmişlerdir. 
E. Özmen - E. Karaman - N. Alkış 13/3 (2021) 2759-2779

E-ticaret sitesinde karşılaştıkları reklamlar hakkında fikirlerinin alındığı site reklam görüşleri teması altında oluşturulan kodlar ve görüş dağılımları Şekil 5'de sunulmuştur.
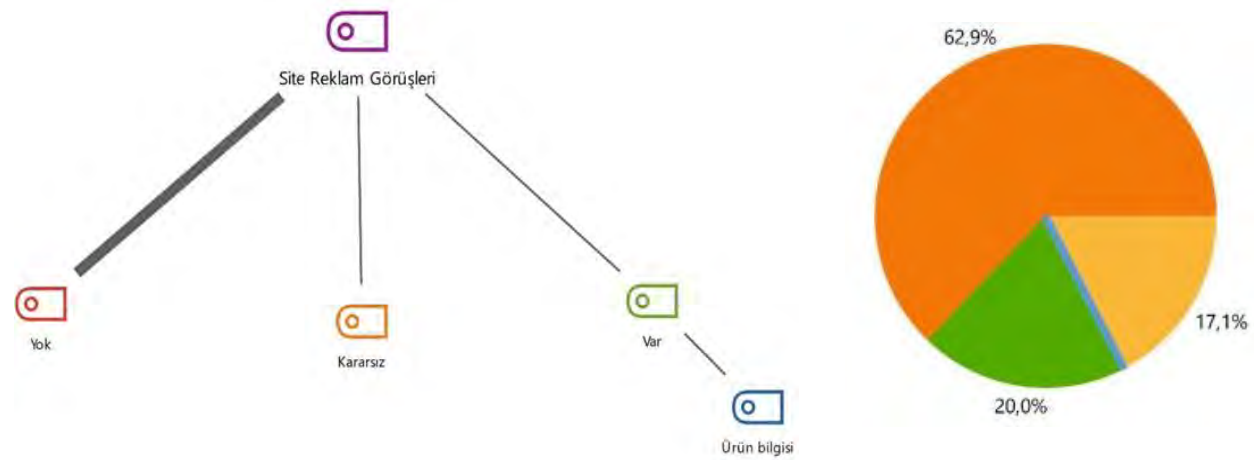

Şekil 5. Site Reklam Görüşleri Kodları ve Görüş Dağılımları

Site reklam görüşleri teması altında oluşturulan 3 ana kod bulunmaktadır. Katılımcı görüşlerinden hareketle site içerisinde reklam bileşeni ile karşılaşmadığını ifade eden görüşler "yok" kodu, karşılaşıp karşılamadığını hatırlamayanlar "kararsız" kodu ve karşılaştığını hatırlayanlar "var" kodu altında toplanmıştır. "Var" kodu altında bulunan ikinci seviye alt kodu "ürün bilgisinde" ise reklam olduğunu ve hangi ürünle ilgili olduğu bilgisini veren görüşler bulunmaktadır. Katılımcı görüşlerinin büyük bir çoğunluğu e-ticaret sitesi içerinde herhangi bir reklam olmadığı \%62,9 (22) yönündedir. Görüşlerin \%20 (10)si reklam varlığına yönelik olmasına rağmen bu görüşlerden sadece 3 tanesi ürün bilgisi belirtmektedir. Geriye kalan görüşler $(\% 17,1(6))$ ise reklamın olup olmadığı hakkında net bir ifade ortaya koymamıştır. Tablo 3 'de reklam görüşleri ve katılımcıları bilgileri bulunmaktadır.

Tablo 3. E-ticaret Sitesi Katılımcı Reklam Görüşleri

\begin{tabular}{|c|c|c|}
\hline Katılımcilar & Görüş & Kod \\
\hline XELÜ1 & $\begin{array}{l}\text { "Să̆da ve solda reklam vardı fakat ilgimi çekmedi. Odak noktam alacă̆ım ürün ve } \\
\text { alternatif ürünlerdi." }\end{array}$ & Var \\
\hline $\begin{array}{l}\text { YELÜ1, } \\
\text { YKLÜ1, YKÜ1 }\end{array}$ & $\begin{array}{l}\text { "Ürünlerden ziyade genelde profesörlerin isimleri vardı să̆ tarafta sadece onları } \\
\text { hatırlıyorum... Sitenin sağ kısmında kendi ürünleriyle ilgili reklamlar gördüm..." }\end{array}$ & Var \\
\hline ZKL1, ZKÜ2 & $\begin{array}{l}\text { "Evet, şampuan olabilir... Evet, karşılaştım, vitamin takviyesi ürünleriyle ilgili } \\
\text { ürünler... Alışveriş sürecinde karşılaşmadım sadece ana ekranda karşılaştım..." }\end{array}$ & Var \\
\hline $\begin{array}{l}\text { XEL2, } \\
\text { XKLL2, } \\
\text { XEÜ1, } \\
\text { XEÜ2, } \\
\text { XKÜ2, } \\
\text { XKÜ1, }\end{array}$ & $\begin{array}{l}\text { "Hayır, karşılaşmadım, yoktu... Karşılaşmadım. En güzel yönü de buydu... Gözüme } \\
\text { çarpmadı. Hayır, bir reklam görmedim..." }\end{array}$ & Yok \\
\hline $\begin{array}{l}\text { YEL2, } \\
\text { YKÜ2, } \\
\text { YEÜ1, } \\
\text { YEÜ2, } \\
\text { YKLÜ2 }\end{array}$ & $\begin{array}{l}\text { "Hayır karşılaşmadım. En güzel özelliklerinden biri de buydu... Herhangi bir reklam } \\
\text { görmedim... Gözüme çarpan bir reklam olmadı." }\end{array}$ & Yok \\
\hline $\begin{array}{l}\text { ZEL1, ZEL2, } \\
\text { ZKL2, ZKÜ1, } \\
\text { ZEÜ1, ZEÜ2 }\end{array}$ & $\begin{array}{l}\text { "Karılaşmadım... Reklamları çok fark etmedim. Karşılaşmadım... En güzel tarafı da } \\
\text { buydu." }\end{array}$ & Yok \\
\hline
\end{tabular}


XEL1, YEL1,

YKL2, XELÜ2,

XKLÜ2,

"Dikkat etmedim... Dikkatimi çekmedi... Emin değilim..."

Kararsiz

YELÜ2

Reklam görüldüğg̈nü ifade eden görüşlerde $X$ kuşağı katılımcılarından sadece 1 katılımcı yer alırken 1 Y kuşağı ve $2 \mathrm{Z}$ kuşağı katılımcısı ürün bilgisi verebilmiştir. Kuşaklardaki katılımcılardan reklam olmadığını ifade eden görüşlerde gözlerine çarpmadığını ve reklamlarla karşılaşmadıklarını ifade etmişler, $X$ ve $Y$ kuşağı katılımcıları da bunun hoşlarına gittiğini ifade etmiştir. Kararsız ifadelerde ise $\mathrm{Z}$ kuşağı yer almamıştır.

Katılımcıların e-ticaret sitesi üzerinden gerçekleştirdikleri alışveriş sürecine yönelik kullanım görüşleri temasında yer alan kodlar ve görüş dağılımları Şekil 6'da yer almaktadır.

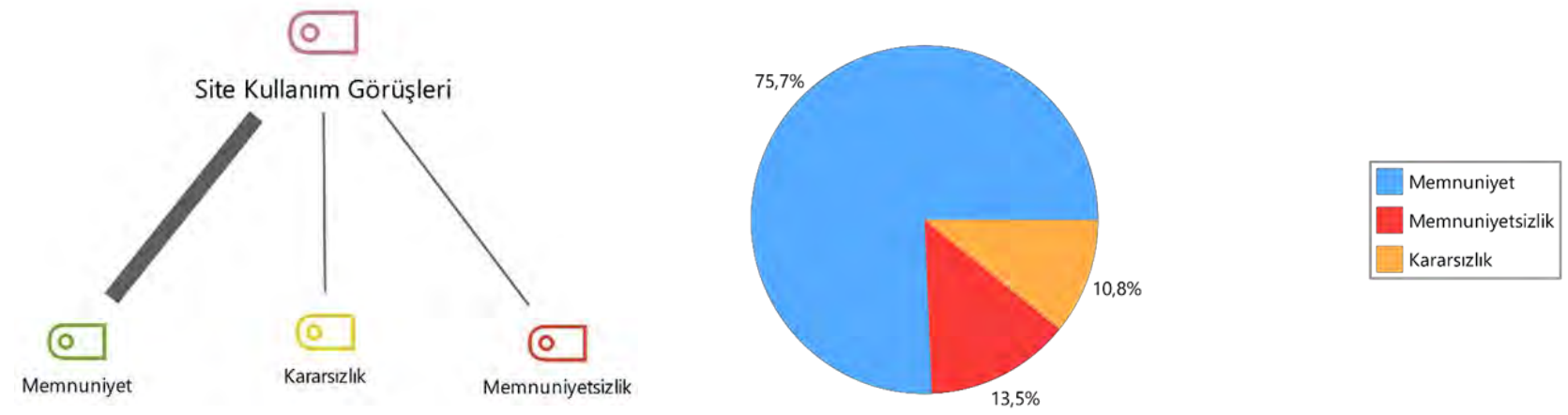

Şekil 6. Site Kullanım Görüş Kodları ve Dağılımları

Katılımcıların site kullanımları ile ilgili belirttikleri görüşler memnuniyet, kararsızlık ve memnuniyetsizlik olmak üzere üç alt koddan oluşmaktadır. Katılımcı görüşlerinin \%75,7 (28)'si söz konusu e-ticaret sitelerini kullanmaktan memnuniyet duyulduğunu ifade ederken memnuniyetsizlik belirten görüşler \%13,5 (5) dilimindedir. Diğer görüşler ise kararsızlık bildirmektedir (\%10,8 (4)). Katılımcı görüşleri ve oluşturulan alt kodlar doğrultusunda kullanım görüşleri ve bu kodlara dâhil olan katılımcı bilgileri Tablo 4'de verilmiştir.

Tablo 4. Katılımcıların E-ticaret Sitesi Kullanım Görüşleri

“Genel olarak memnun ediciydi. Memnun ediciydi, basit bir kullanımı

XEL1, XEL2, vardı... İstediğim şeye hemen ulaştım. Kullanılabilir ve hızl. Memnun

XKL1, XKL2, ediciydi, Kullanımı kolaydı ve güvenilirlikön plana alınmıştı... Kullanımı

XEÜ2, XKÜ1， kolaydı, budan sonra kullanacă̆ım ve çevreme de önereceğim... Bana hitap

XKÜ2, XELÜ1, eden birçok ürünün olduğunu gördüm, memnun ediciydi... Çeşitliliğinin

XELÜ2, XKLÜ1, fazla olması cazip geldi... Çok memnun edici, kullanımı kolay,

XKLÜ2 akademisyenlerin de referans olduğu bir site... Memnun kaldım... Bütün ürünleri bir arada bulmam güzel..."

"Memnun ediciydi, kolaydı ve hızlıydı... Memnun ediciydi, çünkü insanlar aradığı özelliklerde her türlü ürünü bulabiliyorlar. Bu yüzden de

YEL1, YEL2,

YKL1, YKÜ2,

YEÜ1, YELÜ1,

YKLÜ1, YKLÜ2 kullanan kişi rahatlikla siteyi herkese önerebilir... Memnun ediciydi..

Organik ürünler olduğu için ve kullandıklar renkleri beğendiğim için

memnun kaldım. Organik ürünler cezbedici, memnun ediciydi... Organik

ürünlerin olması beni cezbetti... Memnun ediciydi. Tanıdığım kişilerin

isimlerini gördü̆̆̈̈m için bana güven verdi ve memnun kaldım..."
Memnuniyet

Memnuniyet 
"Memnun edici bir siteydi, çevreme ve arkadaşlarıma önereceğim... ZEL1, ZEL2, Memnun ediciydi, çünkü her insanın sevebileceği temizlik ve bakım ZKL2, ZKÜ2, ürünleri satılıyor... Hem herkese hitap ettiği için hem kullanımı kolay ZEÜ1, ZEÜ2 olduğu için hem de ürün çeşitliliği açısından memnun kaldım... Memnun ediciydi, çünkü ürünler etkileyiciydi... Memnun ediciydi. Karmaşık değildi güzel buldum..."

XELÜ1

Memnuniyetsizlik

YKÜ1, YELÜ2

"Memnun edici değildi. Aradığım ürünleri bulamadım... Memnun edici değildi. Bir daha kullanacağımı düşünmüyorum..."

Memnuniyetsizlik

YKL2, YEÜ2,

“Orta derecede memnun ediciydi... Daha önce alıştığımız altyapılara göre

ZKÜ1, ZKL1 biraz daha karmaşık bir altyapısı var ama yine de kullanılabilir... Kararsizım..."

X kuşağında bulunan katılımcılar kullanım durumu ile ilgili sitenin kullanılabilir, basit ve hızlı olma noktasında memnuniyet görüşü belirtirken memnuniyetsizlik görüşü bildiren bir katılımcı stokta olmayan ürünlerin yer almasına değinmiştir. Memnuniyet bildiren katılımcların çoğunu $X$ kuşağı oluştururken kararsızlık görüşünde hiç yer almamışlardır. Diğer taraftan $Y$ kuşağı katılımcılarının çoğunluğu site kullanımlarından memnuniyet duymalarını kolay, hızlı ve ürün içerikli görüşlerle belirtirken çevrelerine önereceklerini söyleyerek bu görülerini desteklemişlerdir. $Z$ kuşağ 1 katılımcı görüşleri ise sitenin herkese hitap ettiğini ve memnun edici bir kullanımı olduğunu ifade etmişlerdir. $\mathrm{Y}$ ve $\mathrm{Z}$ kuşağ ${ }_{1}$ katılımcılarından ikişer katılımcı kullanım durumlarında kararsızlık duyduklarını ifade etmişlerdir.

E-ticaret sitesinde alışveriş sürecini tamamlayan katılımcılara site beğeni durumları sorulmuş ve görüşleri alınmıştır. Alınan görüşler çerçevesinde site beğeni görüşleri teması altında oluşturulan kodlar Şekil 7'de sunulmuştur.

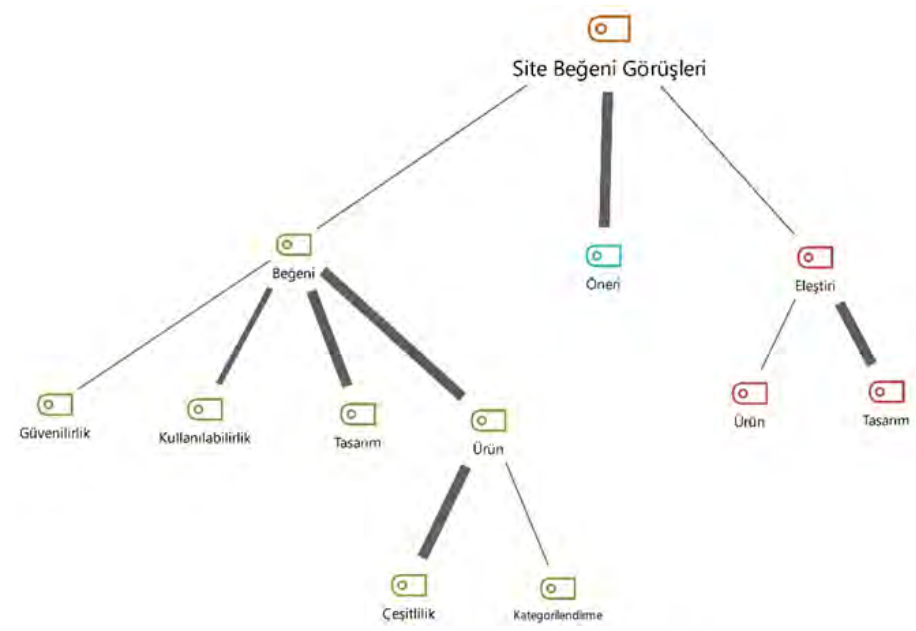

Şekil 7. E-ticaret Sitesi Beğeni Görüş Kodları

Site beğeni görüşleri teması altında oluşturulan beğeni, öneri ve eleştiri alt kodları bulunmaktadır. Katılımcıların beğeni görüşleri kodu altında güvenilirlik, kullanılabilirlik, tasarım ve ürün olmak üzere dört tane ikinci seviye alt kod bulunmaktadır. Ürün alt kodunu oluşturan görüşler ise çeşitlilik ve kategorilendirme olmak üzere iki ayrı üçüncü seviye alt kod altında toplanmıştır. Eleştiri alt kodunu ise ürün ve tasarım olmak üzere iki tane ikinci seviye alt kodu oluşturmaktadır. Öneri alt kodu altında farklı bir seviyede kodlama yapılmamış görüşler tek kod altında değerlendirilmiştir. Katılımcıların site beğeni görüşlerindeki belirlenen kodları katılım durumları Şekil 8'de verilmiştir. 
E. Özmen - E. Karaman - N. Alkış 13/3 (2021) 2759-2779
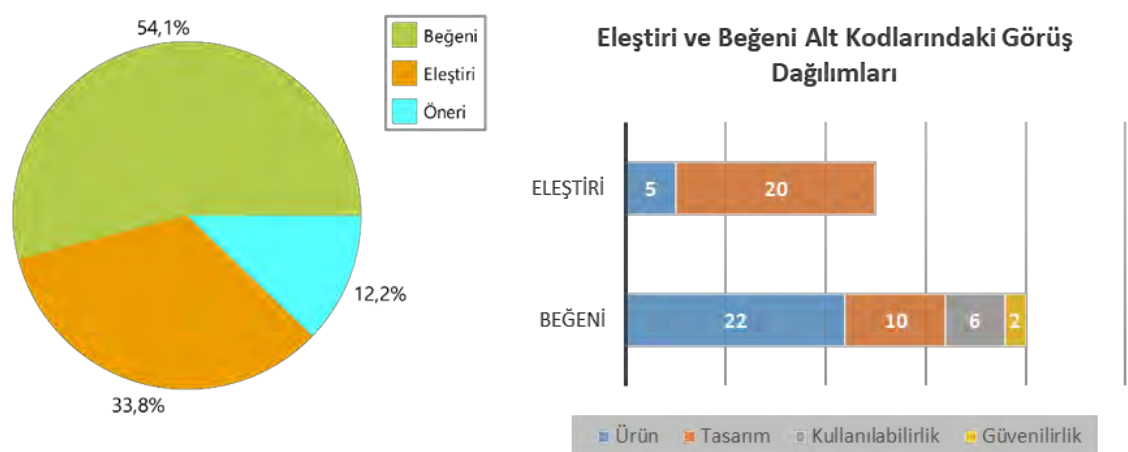

Şekil 8. Katılımcıların E-ticaret Sitesi Beğeni Görüşü Dağılımı

Katılımcıların site beğeni görüşlerinin büyük bir çoğunluğu beğenen olarak görülmektedir. Görüşlerin \%33,8 (25)i eleştiri olarak değerlendirilirken \%12,2(9) si öneri olarak değerlendirilmiştir. Eleştiri ifade eden görüşlerin çoğunluğunu tasarım kodu oluştururken Ürün kodu beğeni kodunun büyük bir bölümü olarak görülmektedir. Diğer taraftan kullanılabilirlik ve güvenilirlik alt kodlarında beğeni görüssleri yer alırken eleştiri görüşleri bu alt kodlarda bulunmamaktadır. Beğeni görüşleri ile ilgili katılımcı yorumları ve bilgileri Tablo $4.45^{\prime}$ de sunulmaktadır.

Tablo 5. E-ticaret Sitesi Katılımcı Beğeni Görüşleri

\begin{tabular}{|c|c|c|}
\hline Katılımcilar & Görüş & Kod \\
\hline $\begin{array}{l}\text { XEL1,XEL2, } \\
\text { XKL1, XKL2, } \\
\text { XKÜ1, XKÜ2, } \\
\text { XEÜ2, XKLÜ1, } \\
\text { XKLÜ2, XELÜ1, } \\
\text { XELÜ2 }\end{array}$ & $\begin{array}{l}\text { "Ürüne kolay ulaşmak ve sistemi basit bir hale getirmeleri hoşuma gitti... Ödeme } \\
\text { bölümü çok hılıydı herhangi bir sorun yaşamadım... Kullandıkları renk seçimini } \\
\text { uyumlu buldum. Alana özel bir sayfa olduğunu düşünüyorum... Renk seçimlerini } \\
\text { uyumlu buldum. Web tasarımı çok güzeldi... Ürünleri kolay bir şekilde görebiliyorum. } \\
\text { Ürünler doğru bir şekilde sınıflandırılmıştı... Güvenilir... Profesörlerin ürünlerine } \\
\text { daha kolay bir şekilde ulaşmak da güzeldi... Ürünlerin doğal ve sağllklı olması en } \\
\text { beğendiğim nokta oldu... Orijinal ürünlerin olması, kategoriler ve ayrılma şekilleri } \\
\text { güzel..." }\end{array}$ & Beğeni \\
\hline $\begin{array}{l}\text { YEL1, YEL2, } \\
\text { YKL1, YKL2, } \\
\text { YEÜ1, YEÜ2, } \\
\text { YKÜ1, YKÜ2, } \\
\text { YKLÜ1, } \\
\text { YKLÜ2, } \\
\text { YELÜ1, } \\
\text { YELÜ2 }\end{array}$ & $\begin{array}{l}\text { Kullanımının kolay olması ve } 3 d \text { ödemenin olmasını beğendim... Ürün çeşitlilĭğiçoktu... } \\
\text { Illk kez girmeme rağmen kullanımı kolaydı... Bay bayan özelliklerini ayırması ve } \\
\text { ürünlerde erkek reyonunda dahi sınıflandırma yapması güzel olmuştu... Kategorilere } \\
\text { ayrılmış, aradı̆̆ı̆ her şeyin bulunabilir olması... Bitkisel ürünlerin olması ve çeşitlerin } \\
\text { çok olması güzeldi... Kullandıkları renk ve organik ürünlerin olmasını beğendim... } \\
\text { Kullanılan renklerin sade oluşunu beğendim... Sekmelerin açıklayııı olmasını } \\
\text { beğendim... Doğal ürünler olması ve bitkisel ürün olarak ön planda olması..." }\end{array}$ & Beğeni \\
\hline $\begin{array}{l}\text { ZEL1, ZEL2, } \\
\text { ZKL1, ZKL2, } \\
\text { ZKÜ1, ZKÜ2, } \\
\text { ZEÜ1, ZEÜ2 }\end{array}$ & $\begin{array}{l}\text { "Ürünlerin genellikle kullanılabilecek ürünler... Ürün çeşitliliği. Sayfanın kullanışı } \\
\text { kolay... Her yaştan ve teknoloji ile arası çok iyi olmayan insanların bile rahatlıkla girip } \\
\text { kullanabileceği bir site... Fiyatların uygunluğu ve kategoriler güzel ayrılmasını } \\
\text { beğendim... En ince detaya kadar ayrllmıştı... Ürünlerin organik olması beni çok } \\
\text { etkiledi... Ürünlerin liste halinde çoklu görünmesi ve ürünlere dair bilgilerin olmasını } \\
\text { beğendim..." }\end{array}$ & Beğeni \\
\hline
\end{tabular}


XEL2, XKL1，

XKÜ2,

XKLÜ1,

XELÜ1,

XELÜ2

YEL1, YKL1, kullandıkları fotoğraflar profesyonel olmadı̆̆ı̆ndan, kurumsal bir izlenim de vermediği

YKL2, YKÜ1,

YKÜ2, YEÜ1,

YEÜ2, YKLÜ1,

YKLÜ2,

YELÜ1,

YELÜ2

ZEL2, ZEÜ1,

ZEÜ2, ZKL1,

ZKÜ2

XEL2, XELÜ1

YELÜ1

ZEÜ1, ZKÜ1

"Karmaşık olduğunu düşünüyorum. Tüm kategoriler adı altında bir sürü seçenek var bunların simıflandırlması gerektiğini düşünüyorum... Ayrıtılı olması gerekiyor... Ürünlerin markaları daha açık bir şekilde belirtilebilir... Sayfanın rengini beğenmedim... Filtreleme olmaması çok yorucuydu... Giriş biraz karışık olmuştu..."

Eleştiri için güvensizlik veriyor... Beğendiğim ürünler stokta yoktu... Ecza deposu adıyla açıp gıda ürünlerini de aynı şekilde bulundurması rahatsı edici... Filtreleme olmamasını beğenmedim... Sistemin görünümü ve filtreleme eksiği... Almak istediğim ürünlerin stokta olmaması beni rahatsız etti... Ürünün özelliklerini açıklayıcı bulmadım. Üye olurken üye ol kısmına basmama rağmen üye girişinin öncelikli açılması beni rahatsız etti... Son kısımda onay mesajını kırmızı renkte vermesi bana bir şeylerin yanlış gittiği izlenimi verdi... Karışık buldum... Aradığım ürünü bulamadım... Herhangi bir kategoriye girdiğimde farklı kategoride olan ürünlerin de olduğunu gördüm. Bu durum rahatsiz ediciydi...

"Kategorilendirilmesinde sorun vardı... Site çok basit. Ürünlerin stokta olmayışı... Ana sayfa çok ilkel görünüyor.... Ürünler çok karışıktı... Biraz daha düzenli olması gerekiyor... Ürünlerin filtreleme ve siralama bölümünün olması gerekiyor... Estetik Eleştiri bulmadım. Amatörce görünüyor ve sayfayı ciddiye almakta zorlanıyorum..."

"Takip sayacı önemli ve olması gerekiyor. Geliştirilebilir olduğunu düşünüyorum... Ana sayfadaki reklam kısmı düzeltilmeli... Ürünlerin kategorize olması konusunda bir çalışma yapılması gerekiyor... Daha profesyonel olması gerekiyor... Filtreleme seçeneğ $i$ eklenmeli... Erkek kadın ayrımı ve kampanyalı ürünler için bir seçenek olması gerekiyor..."

"Daha orijinal reklamlar çekilebilirdi... Karmaşıklık giderilebilir... Filtreleme seçeneğ $i$ eklenebilir... Stokta olan olmayan ürünler ayrıştırılabilir..."

Öneri

"Biraz daha indirimli ürünler varsa onlar daha çok ön plana çıkarılabilir. Kategori kısmı daha basit olabilirdi..."

Tablo 5'de yer alan görüşler ve katılımcı bilgilerinden hareketle beğeni alt kodunda bulunan görüşlerde $\mathrm{X}$ kuşağı katılımcıları renk seçimi, web tasarımı, ürünü kolay bulma ve ürün özellikleri ifadelerine sıklıkla yer vermişlerdir. Y ve Z kuşağı katılımcıları daha çok ürün çeşitliliği ve özellikleri, kullanım kolaylığı gibi noktalar üzerinde görüş bildirmiştir. Eleştiri ve öneri kodunda ise neredeyse tüm kuşaklar filtreleme ve sıralama özelliğinin olmamasını büyük bir eksiklik olduğunu ve bunun rahatsız edici olduğunu aktarmıştır. Aynı şekilde stokta olmayan ürünlerin gösterilmemesi gerektiğini ifade eden katılımcılar renk ve tasarım konusunda da eleştiri ve önerilerde bulunmuşlardır. Üyelik sayfasının karışık ve yorucu olduğunu söyleyen katılımcılar ileti mesajlarının da daha iyi tasarlanmasını ve kategorilendirme noktalarının gözden geçirilmesi gerektiğini ifade etmiştir. Son olarak site hakkında genel görüşlerini aldığımız katılımcıların bu tema altında belirlenen alt kodları bu kodlara katılımcıların dağılım oranları Şekil 9'da sunulmuştur. 
E. Özmen - E. Karaman - N. Alkış 13/3 (2021) 2759-2779
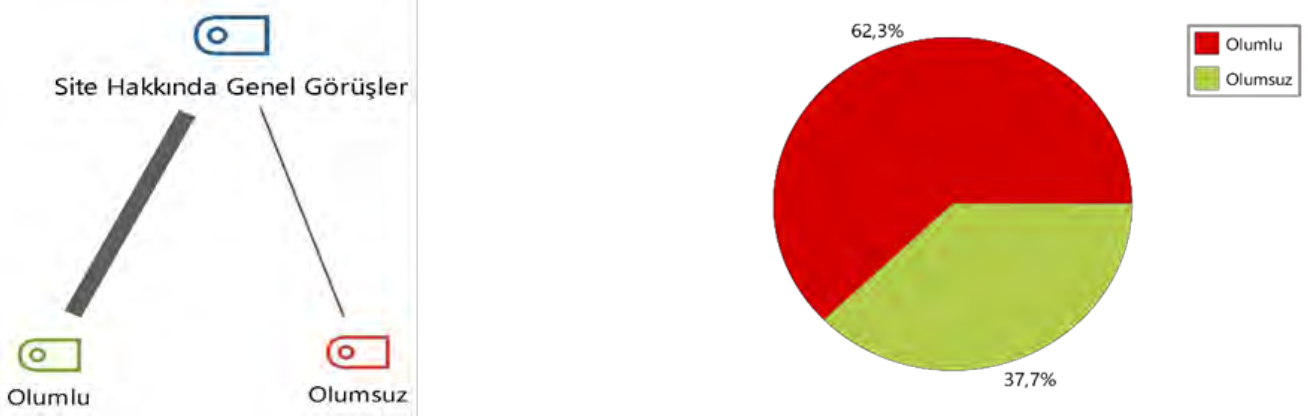

Şekil 9. Site Hakkında Genel Görüş Kodları ve Dağılımları

Katılımcıların site hakkında genel görüş temaları altında belirlenen olumlu ve olumsuz alt kodları görülmektedir. Bu kodlara katılımcı görüşlerinden \%62,3 (33)ü olumlu ifadeler barındırırken $\% 37,7$ (20)sinde olumsuz ifadeler yer almaktadır. Olumlu ve olumsuz kodlar içinde yer alan görüşler ve katılımcı bilgileri Tablo 6' da sunulmaktadir.

Tablo 6. E-ticaret Sitesi Hakkında Katılımcı Genel Görüşleri

\begin{tabular}{|c|c|}
\hline Katılımcilar & Görüş \\
\hline XEL1, XEL2, & $\begin{array}{l}\text { "Gayet güzeldi. Kullanımı da basit. Kullanılabilir bir site... Hızlı ve güvenilir... Site } \\
\text { çok açık ve net ifadelerle kullanıcının kolaylı̆̆ıı düşünerek hazırlanmış. Benim hoşuma }\end{array}$ \\
\hline XKL1, XKL2, & gitti... Kullanım kolay bir site. Siteyi beğendim... İlk kez kullanmama rağmen hiç \\
\hline XEÜ2, XKÜ1, & $\begin{array}{l}\text { zorlanmadım... Kullanımı kolaydı... Kullanılabilir, güzel bir siteydi... Ürünleri de } \\
\text { hoşuma gitti, kullanmak isterim... Kullanımı rahattı, ürünleri de kolay bulabildim... }\end{array}$ \\
\hline XKÜ2, XELÜ2, & Doktorların bu sitede kendi ürünlerinin olmasından dolayı güvenilir buluyorum... \\
\hline $\begin{array}{l}\text { XKLÜ1, } \\
\text { XKLÜ2 }\end{array}$ & $\begin{array}{l}\text { Genel olarak bakıldığında kullanışlı bir site... Farklı bir alanda geliştirilmiş olduğunu } \\
\text { düşünüyorum, dikkat çekici buldum... Farklı ve yaratıcı buldum. Birçok ürünü } \\
\text { kolaylıkla buldum... Aradığım bütün kategorilerin bir sayfada olması güzel..." }\end{array}$ \\
\hline
\end{tabular}

Kod

YEL1, YEL2,

YKL1, YKL2, "Ilk kez kullanmama ră̆men pratik bir şekilde alışveriş yaptım. Kullanımı kolay bir YKÜ2, YEÜ1, site... Her yaşa hitap edebilecek bir kolaylı̆̆a sahipti. Zengin bir içeriği vardı... Site olarak güzel bir yapısı var... Kategorilendirmesi güzel... Güzel tasarlanmış. Renklerini

YEÜ2, YKLÜ1, beğendim, kullanımı basit... Site renkleri sade, kullanışlı, kategorisi geniş, bana güven Olumlu

YKLÜ2, verdi..."

YELÜ2

ZEL1, ZKL1,

ZKL2, ZKÜ1, "Genel olarak ihtiyaçların alınabileceği bir site. Önerebilirim... İhtiyaç dahilinde girip ZKÜ2, ZEÜ1, kullanılabilecek bir site... Kullanımı kolaydı. En eğitimlisinden en eğitimsizine kadar ZEÜ2 herkes kullanabilir... Kullanımı çok zor değildi. Kullanımı kolay bir site... Karmaşık Olumlu değildi. Kolaylıkla her ürünü bulabildim."

XELÜ1, XEÜ1

Sayfada çok fazla resim vardı. Reklam kısmı çok büyüktü. Amatörce hazırlanmış bir site olduğunu düşünüyorum... Güven vermiyor. Buradan alışveriş yapmak tercih edilebilecek bir şey değil... Sitenin kullanımı zor... Verdiğimiz bilgilerin nerede Olumsuz kullanılacağı insanı şüpheye düşürüyor..."

YEL1, YKL1, "Siralama özelliği, markalara göre kategorize etme ya da stokta bulunan bulunmayan YKÜ1, YKÜ2, ürünlerin daha net ayrıştırılması gibi birtakım özellikler eklenebilir... Çok profesyonel ve güvenilir bulmadım... Almak istediğim ürünler stokta yoktu. Ürün seçmekte 


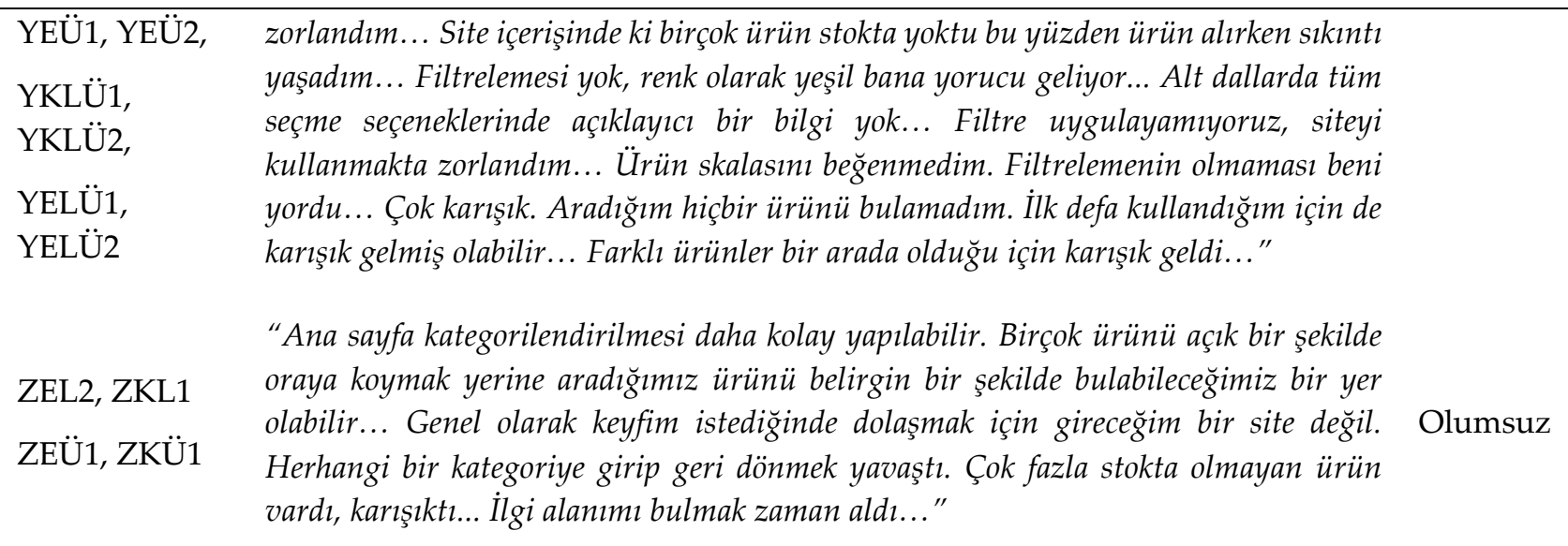

Tablo 6 incelendiğinde katılımcıların olumlu görüşlerini kullanım kolaylığı, ilk kez kullanılmasına rağmen zorluk yaşanmaması, ürünlerin farklı ve yaratıcı olması ifadelerini X kuşağı aktarırken $Y$ kuşağı herkese hitap eden bir site olduğunu sade ve basit tasarlandığını aktarmıştır. $Z$ kuşağı da kullanımının kolaylığı nedeniyle olumlu ifadeler kullanmışlardır. Site hakkında olumsuz görüşlere bakıldığında ise X kuşağı sayfanın amatörce hazırlandığı ve güven vermediğini ifade etmiştir. Y kuşağ 1 ise en çok filtreleme ve sıralama özelliğinin olmaması yönünde olumsuz görüş belirtmiş ve stokta olmayan ürünlerinde gösterilmemesi gerektiğini vurgulamıştır. Z kuşağı gezinim noktasında tercih edilebilecek bir site olarak görmediğini ve karışık bir site olduğunu dile getirmiştir.

E-ticaret sitesi alışveriş sürecini gerçekleştiren katılımcılarla yapılandırılmamış 8 soru içeren mülakat görüşme sonucunda 323 anlamlı görüş alınmış ve bu görüşler 6 ana temaya ayrılmıştır. Bu temalar toplamda 26 alt koddan ve 8 ikinci seviye alt koddan oluşmuştur. Bu kodlardan hareketle oluşturulan kod ağacı Ek 1'de sunulmuştur. Katılımcı görüşleri doğrultusunda en sık kullanılan 100 kelime ile bir kelime bulutu oluşturulmuş ve Şekil 10' da sunulmuştur.

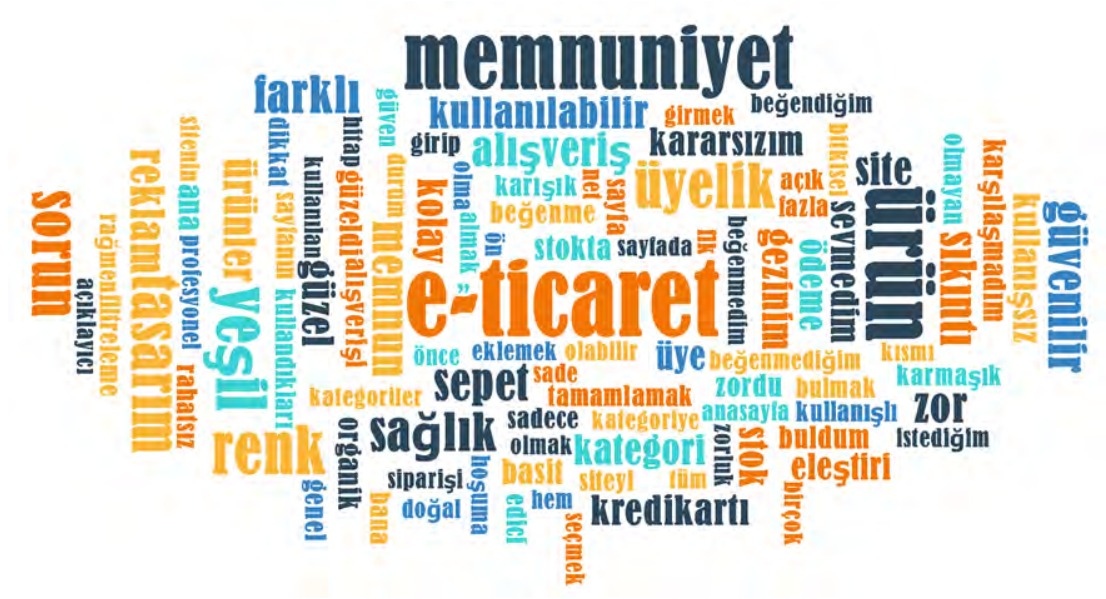

Şekil 13. E-ticaret Sitesi Katılımcı Mülakatları Kelime Bulutu

\section{SONUÇ VE TARTIŞMA}

Bu çalışmada e-ticaret sayfalarında kullanıcıların keşfetme, ürün arama-bulma ve satın alma süreçleri nitel olarak incelenmiştir. Gerçek bir alışveriş sürecinden geçen müşteriler ile e-ticaret sayfası arayüzünün kullanılabilirlik değerlendirilmesi mülakat tekniği ile yapılmıştır. E-ticaret sitesi arayüz kullanılabilirlik değerlendirmesi $X, Y, Z$ kuşaklarında bulunan farklı eğitim seviyelerine sahip kadın ve erkek 32 gönüllü katılımcı ile gerçek bir alışveriş süreci yapılarak tamamlanmıştır. Deneysel çalışmaların doğası gereği çok fazla sayıda katılımcı olmaması sonuçları genelleme noktasında sınırlılık oluştursa da elde edilen bulgulardan hareketle sonuçlar ana hatlarıyla yorumlanmıştır.

Tüm kuşaklardaki katılımcıların büyük bir bölümü üyelik oluşturma görevinde üye girişi bölümünden üye olmaya çalışmışlardır. Katılımcılar verilen görevler arasından üyelik oluşturma adımında yaşadıkları sorunları sıkça ifade etmişlerdir. Bu sonuca benzer olarak Ülger ve Toksarı (2020), site tasarımına önem 
gösterilmesi, eksik bilgilendirme ve yanlış yönlendirmeden kaçınılması, tüketicilerin istedikleri şeylere kısa sürede ulaşabilmeleri ve zaman kaybı yaşamamaları gerektiğini ifade etmiştir. Ana sayfa gezinim görevinde katılımcilar kategori, menü, görsellik ve sadelik gibi noktalarda olumlu yorumlar yaparken renk, ürün konumlandırması, resimler, basitlik, ürün bilgilendirmeleri gibi bölümlerde ise olumsuz görüş bildirmişlerdir. Ana sayfa ile ilgili özellikle renklendirme için öneride bulunmuşlar ve ana sayfanın kendileri için site hakkında önemli ipucu verdiğini belirtmişlerdir. Oliveira, Afonso ve Pinto (2020) de çalı̧̧malarında e-ticaret web sitelerinin ana sayfası kullanıcı için giriş noktası olduğundan, kullanılabilirlik ve erişilebilirlik için birincil hedef olması gerektiğini ifade etmişlerdir. Katılımcıların büyük çoğunluğu alışveriş sürecinde verilen görevlerin kolay olduğunu belirtmiştir. Katılımcıların görüşleri incelendiğinde en kolay görev/ler kapsamında; siparişin tamamlanması, ürün seçimi gibi ifadeler yer alırken en zor görev/ler için üye olmak, kredi kartı bilgilerini girmek, alışverişi sonlandırmak ifadeleri yer almaktadır. Başaran (2014)'da benzer sorunların kaldırılmasına yönelik bulgulara yer vermiş ve e-ticaret sitelerinde tasarımın kullanıcı ile sistem arasındaki etkileşimi sağlayan en önemli husus olduğunu belirtmiştir.

$X$ kuşağı sitenin ilk kez kullanılmasına rağmen zorluk yaşanmaması, ürünlerin farklı ve yaratıcı olması ifadelerini aktarırken $Y$ kuşağı herkese hitap eden bir site olduğunu sade ve basit tasarlandığını aktarmıştır. Site hakkında olumsuz görüşlere bakıldığında ise $X$ kuşağı sayfanın amatörce hazırlandığı ve güven vermediğini ifade ederken $Z$ kuşağı gezinim noktasında tercih edilebilecek bir site olarak görmediğini ve karışık bir site olduğunu dile getirmiştir. Erserim (2019) bu sonuçlara paralel olarak kuşaklar arasında eticarete yönelik tutumları incelediği çalışmasında e-ticaret unsurlarını $\mathrm{Y}$ ve $\mathrm{Z}$ kuşaklarının daha çok benimsediğini en az benimseyen kuşakların ise bebek patlaması ve $X$ kuşağı olduğunu ifade etmiştir. Ayrıca Sharma ve Lijuan (2015) da e-ticaret sitesini tercih etme noktasında web sayfasının kalitesinin önemli olduğunu vurgulamıştır.

Üyelik sayfasının karışık ve yorucu olduğunu söyleyen katılımcılar ileti mesajlarının da daha iyi tasarlanmasını ve kategorilendirme noktalarının gözden geçirilmesi gerektiğini ifade etmiştir. Gürsel (2019) de bu sonuca benzer bir şekilde kullanıcı deneyiminin başarılı bir e-ticaret web sitesinin anahtarı olduğunu ve kullanıcıların işlem yapma kararlarını etkileyen en önemli faktörlerden biri olduğunu ifade etmiştir. Katılımcılar onay mesajlarının kırmızı renkte olmasının tedirginlik oluşturduğunu ifade etmişlerdir. Bu ifade, Xu ve Zhang (2019)'un e-ticaret sitelerinde renk faktörünü ele aldıkları ve göz hareketlerini izleme yöntemi kullandıkları çalışmada negatif anlamlı yerlerde kırmızı pozitif anlamlı noktalarda ise yeşil renk kullanılmasını önerdikleri çalışma ile uyumluluk göstermektedir.

Sonuç olarak çalışma kapsamında alanyazın taramasında ele alınan kullanılabilirlik değerlendirme çalışmalarında sunulan çözüm önerileri ve e-ticaret sektöründeki ihtiyaçlar göz önünde bulundurulmuştur. Çalışmada kullanıcıların alışveriş sürecinde yaşadıkları deneyimleri nitel araştırma yöntemi kullanarak incelemek ve bulgular ışığında alanyazına ve uygulamaya yönelik öneriler sunmak amaçlanmıştır. Çalışmanın gerçek alışveriş sürecinde, gerçek bir arayüz ve gerçek kullanıcılarla yapılmasının yanı sıra farklı özellikteki örneklem gruplarının çalışmaya katılması çalışmanın önemini oluşturan unsurlardandır.

Sonuçlardan hareketle uygulamaya yönelik çeşitli öneriler sunulmuştur. E-ticaret sayfa yöneticileri açısından sonuçlar değerlendirildiğinde, hedef müşterilerinin görüşlerine veya onlardan elde edilen bulgulara web arayüzleri ile ilgili güncellemeler yapabilirler. Arayüz tasarım çalışanları, E-ticaret sitesi ana sayfası tasarımında karışık, göz yorucu ve zihinsel açıdan yük oluşturan tasarımlardan kaçınmalıdırlar. Elde edilen sonuçların renk faktörüne odaklanması da tasarımcılar açısından dikkate alınması gereken bir husus olarak değerlendirilmelidir. Tasarımcılar kullanıcının minimum mental yükle işlem yapmalarını sağlamalıdır. Ürünlere daha hızlı ulaşım açısından tasarımcılar filtreleme seçeneğini daha net bir şekilde tasarlamalı ve sıralama özelliğine tasarım esnasında yer vererek sıralama sonuçlarının özelleştirilebilmesine imkân tanımalıdırlar. Birden fazla web sayfası çalışmaya dâhil edilerek genişletilmesi alanyazına katkısını artırabilir. Bu çalışma kapsamında kuşak, cinsiyet ve eğitim seviyesi ele alınırken, farklı demografik verilerin dahil edilmesi e-ticarete yönelik yapılan önerilerin genellenebilirliği noktasında güçlendirici bir rol oynayacaktır.

Son olarak bu çalışma, alan yazında e-ticaret sitelerinin kullanılabilirliğine yönelik ele alınan konulara ve tavsiyelere derinlemesine araştırma imkânı veren nitel yöntemle geçerlemesinin yapılması ve tartışılması açısından önem taşımaktadır. Ayrıca web sayfaları için erişilebilirlik alanında yapılabilecek değerlendirme çalışmalarının yanı sıra e-ticaret siteleri için oluşturulabilecek kullanılabilirlik ve erişilebilirliği amaçlayan rehber, standart veya prensip çalışmalarına da yol gösterici olma özelliği taşımaktadır. 


\section{KAYNAKÇA}

Akçi, Y., \& Annaç Göv, S. (2015). “Tüketicilerin E-ticaret Algılarının İncelenmesi (Gaziantep ve Adıyaman Örneği)". Mehmet Akif Ersoy Üniversitesi Sosyal Bilimler Enstitüsü Dergisi, 7(3), 413-433.

Akyazı, A. (2018). Dijitalleşen Ticaret: Yaşlı Dostu E-Ticaret Siteleri Üzerine Bir Araştirma. The Turkish Online Journal of Design Art and Communication, 8(4), 602-614.

Alhussein, H., \& Atılgan, K. Ö. (2021). İnternet Sitesi Tasarımının Müşteri Güveni, Müşteri Memnuniyeti ve Satın Alma Niyetine Etkisi. Çankırı Karatekin Üniversitesi İktisadi ve İdari Bilimler Fakültesi Dergisi, 11(1), 351-375.

Arastaman, G., Fidan, İ. Ö., \& Fidan, T. (2018). “Nitel Araştırmada Geçerlik ve Güvenirlik: Kuramsal Bir İnceleme". YYÜ Ĕ̆itim Fakültesi Dergisi, 15(1), 37-75.

Bailey, K. D. (1982). Methods of Social Research. New York: The Free Press.

Başaran, S. (2014). E-ticaret Uygulamalarında Kullanııı Deneyimi. (Yayımlanmış Yüksek Lisans Tezi), İstanbul: Arel Üniversitesi Sosyal Bilimler Enstitüsü

Büyüköztürk, Ş., Kılıç Çakmak, E., Akgün, Ö. E., Karadeniz, Ş., \& Demirel, F. (2014). Bilimsel Araştırmanın Temelleri. Bilimsel Araştırma Yöntemleri (s. 1-36). içinde Ankara: Pegem Akademi.

Coşkun Karadağ, N. (2005). “Elektronik Ticarette Vergilendirme Sorunları ve Uluslar Arası Düzeyde Çözüm Arayışlarının Türkiye Açısından Değerlendirilmesi". Çukurova Üniversitesi Sosyal Bilimler Enstitüsü Dergisi, 14(1), 153-169.

Erbaşlar, G., \& Dokur, Ş. (2008). Elektronik Ticaret. Ankara: Nobel Yayın Dağıtım.

Erer, B. (2020). “Örgütsel Sessizlik Davranışının X, Y ve Z Kuşağı Açısından”. Sosyal Bilimler Meslek Yüksekokulu Dergisi, 23(2), 577-589.

Erserim, G. (2019). Kuşaklar Arasında E-ticaret'e Yönelik Tutum Farklllklarının Değerlendirilmesi. (Yayımlanmış Yüksek Lisans Tezi), İstanbul: Bahçeşehir Üniversitesi Sosyal Bilimler Enstitüsü

eticaret.gov.tr. (2021). 2020 Yllı E-ticaret Verileri Açılandı. Nisan 10, 2021 tarihinde https://www.eticaret.gov.tr/haberler/10040/detay adresinden alındı

Gürbüz, A., Ayaz, N., \& Albayrak, M. (2015). E-Ticarette tüketici satın alma karar süreci: Salzburg-Ankara örneği. Isşletme Araştırmaları Dergisi, 7(3), 377-394.

Gürsel, U. (2019). USer Experience The Key of A Succesfsfull E-commerce Website.

Hanson, W., \& Kalyanam, K. (2006). Internet Marketing and e-Commerce. South-Western College Publications.

Koufaris, M. (2002). “Applying the Technology Acceptance Model and Flow Theory to Online Consumer Behavior". Information Systems Research, 13(2), 205-223.

Laudon, K. C., \& Traver, G. (2011). E-commerce. England: Pearson/Addison Wesley.

Lohse, G. L., \& Spiller, P. (1998). “Electronic Shopping”. Communications of the ACM, 41(7), 81-87.

Lohse, G., \& Spiller, P. (1999). “Internet Retail Store Design: How the User Interface Influences Traffic and Sales". Journal of Computer-Mediated Communication, 5(2).

Maxwell, J. (1992). “Understanding and Validity in Qualitative Research". Harvard Educational Review, 62(3), 279-301.

Mohd, N. A., \& Zaaba, Z. F. (2019). "A Review of Usability and Security Evaluation Model of E-commerce". The Fifth Information Systems International Conference, (s. 1199-1205).

Montoya-Weiss, M., Voss, G., \& Grewal, D. (2003). “Determinants of Online Channel”. Journal of the Academy of Marketing Science Use and Overall Satisfaction with a Relational, Multichannel Service Provider, 31(4), 448-458. 
E. Özmen - E. Karaman - N. Alkış 13/3 (2021) 2759-2779

Nielsen, J. (2002, Mayıs 11). Top Ten Guidelines for Homepage Usability. Mart 20, 2021 tarihinde https://www.nngroup.com/articles/top-ten-guidelines-for-homepage-usability/ adresinden alınd1

Oliveira, R. P., Afonso, A. P., \& Pinto, A. S. (2020). E-Commerce Website Accessibility Evaluation: Case Study in Portugal. Şubat 10, 2021 tarihinde https://www.researchgate.net/profile/Ana-Afonso4/publication/347521148_E-

Commerce_Website_Accessibility_Evaluation_Case_Study_in_Portugal/links/5ff1eb68299bf14088694 ac4/E-Commerce-Website-Accessibility-Evaluation-Case-Study-in-Portugal.pdf adresinden alınd1

Ortaş, İ. (2010). “Etik İlkeler ve Davranış Kuralları Açısından Bilimsel Etik Kurullarının Gerekliliği”. Türk Kütüphaneciliği, 24(1), 94-100.

Öztürk, Ö. (2019). “User Experience of E-commerce Platforms for Women: Turkish Case”. Galatasaray Üniversitesi İletişim Dergisi, 30, 79-90.

Patton, M. Q. (1990). Qualitative Evaluation and Research Methods (2 b.). London: Sage Publication.

Sharma, G., \& Lijuan, W. (2015). The effects of online service quality of e-commerce Websites on user satisfaction. The Electronic Library

Strauss, A. L., \& Corbin, J. (1990). Basics of QualitativeResearch: Grounded Theory Proceduresand Techniques. Newbury Park: CA: Sage.

TÜBA. (2002). Bilimsel Araştırmada Etik ve Sorunları. Ankara: Türkiye Bilimler Akademisi Yayınları. Mart 20, 2021 tarihinde http://www.tuba.gov.tr/tr/yayinlar/suresiz-yayinlar/raporlar/tuba-bilimselarastirmada-etik-ve-sorunlari adresinden alındı

Uygur, E. (2010). E-Ticaret ve Türkiye'deki Durumu. (Yüksek Lisans Tezi), Ankara: Atılım Üniversitesi Sosyal Bilimler Enstitüsü

Ülger, Y. T., \& Toksarı, M. (2020). E-Ticaret Sitelerinin Kullanılabilirliği ve Başarısını Etkileyen Faktörlerin Belirlenmesi. Giresun Üniversitesi Ikktisadi ve İdari Bilimler Dergisi, 6(2), 116-128.

Van Duyne, D. K., Landay, J. A., \& Hong, J. I. (2003). The Design of Sites: Patterns, Principles and Processes for Crafting a Customer-Centred Web Experience. Boston, USA: Addison-Wesley.

Whinston, A., \& Kalakota, R. (1996). Frontiers of Electronic Commerce. California, USA: Addison Wesley Longman Publishing.

Whittemore, R., Chase, S. K., \& Mandle, C. L. (2001). “Validity in Qualitative Research". Qualitative Health Research, 11(4), 522-537.

Xu, C., \& Zhang, Q. (2019). “The Dominant Factor of Social Tags for Users' Decision Behavior on E-Commerce Websites: Color or Text". Journal of the Association for Information Science and Technology, 70(9), 942-953.

Yıldırım, A., \& Şimşek, H. (2016). Sosyal Bilimlerde Nitel Araştırma Yöntemleri (11. b.). Ankara: Seçkin Yayınları.

Yörük, M. A. (2001). Elektronik Ticaret. Uluslararası Ekonomik Sorunlar Dergisi(1). Nisan 10, 2021 tarihinde https://www.mfa.gov.tr/elektronik-

ticaret.tr.mfa\#: :text=I\%2DElektronik\%20Ticaretin\%20Temel\%20Ara\%C3\%A7lar\%C4\%B1,alt\%C4\%B 1\%20temel\%20ara\%C3\%A7\%20olarak\%20say\%C4\%B1lmaktad\%C4\%B1r. adresinden alınd 1 
E. Özmen - E. Karaman - N. Alkış 13/3 (2021) 2759-2779

EK 1. TEMA VE KOD AĞACI

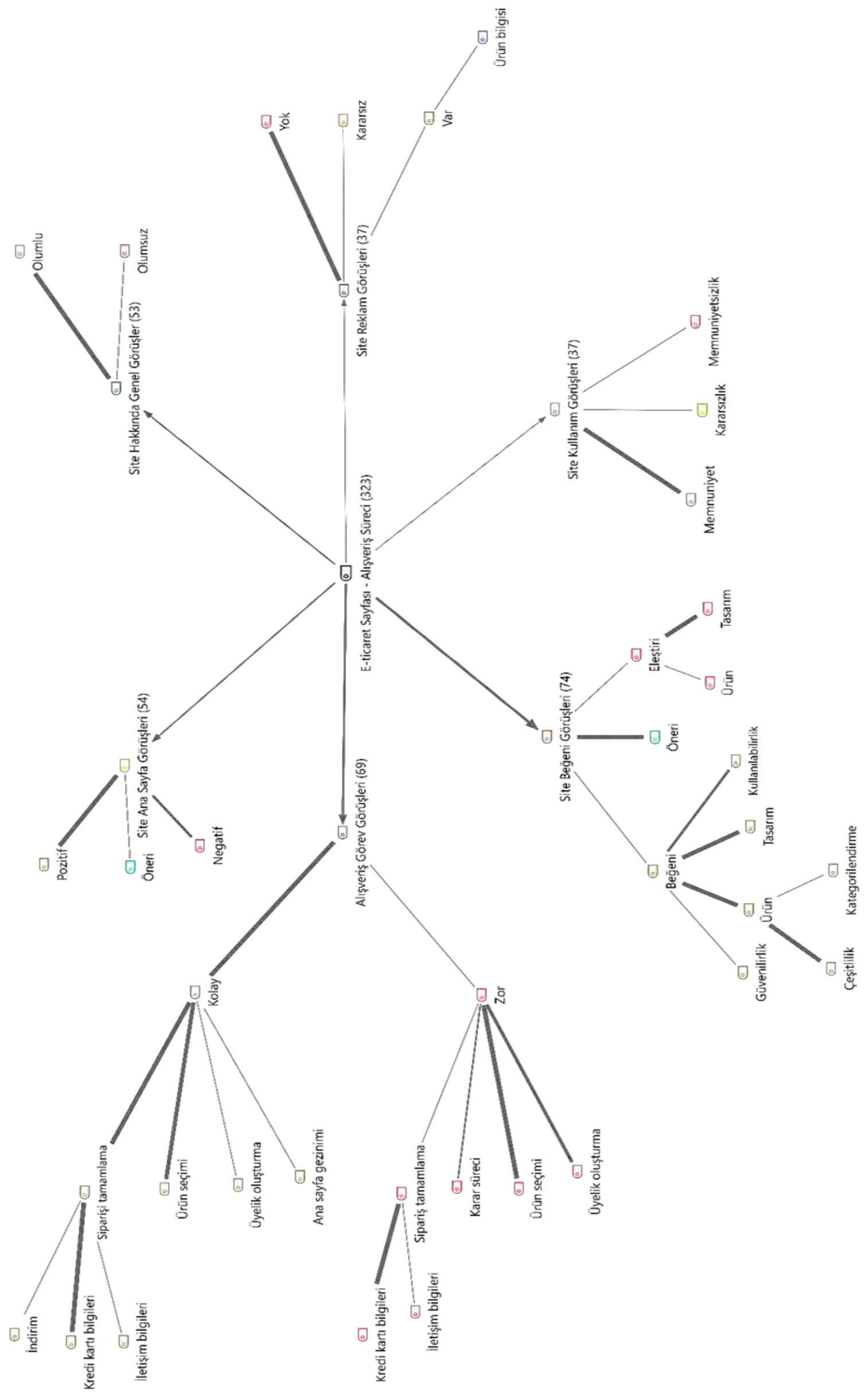

